\title{
Los libros de cabildo y la temprana historia política del Perú colonial
}

\section{Libros de Cabildo and the Early Political History of Colonial Peru}

\author{
MARCOS ALARCÓN OLIVOS \\ Pontificia Universidad Católica del Perú \\ marcos.alarcon@pucp.pe
}

El objetivo de esta nota es discutir, a partir del análisis de los libros de cabildo disponibles para la gobernación de Nueva Castilla y posterior virreinato del Perú, entre 1532 y 1548, los alcances y los límites de este tipo de fuente para la comprensión de las dinámicas de poder establecidas en los primeros años de conquista de dicho territorio. Se sostiene que su uso sistemático permite una relectura de la temprana historia política del Perú colonial, alternativa a la de una visión centrada en el desarrollo del Estado y en el papel organizador de Francisco Pizarro; de esta manera, esta fuente es útil para profundizar en el conocimiento de la complejidad política del periodo. Para ello, primero se discute el carácter documental de los libros de cabidos, así como el uso que los historiadores han realizado de ellos. En segundo lugar, se plantea el valor de su uso sistemático. Finalmente, a partir de dos ejemplos, se muestra su utilidad y se sugiere cómo aprovechar sus limitaciones.

Los cabildos fueron una institución clave en la conquista de América. Con un territorio que desbordaba las fronteras del mundo conocido y con recursos económicos y humanos en aquellos tiempos limitados, la Corona era incapaz aún de desplegar un cuerpo de servidores que controlaran sus recientes posesiones. Frente a ello, los grupos de expedicionarios debieron 
ocuparse por sí mismos del gobierno de las tierras que iban ganando. En esta tarea se valieron del único recurso institucional que les permitía establecer un cierto orden, control y gestión de los nuevos espacios: los cabildos. Cualquiera fuese el nombre con el que se le designase, el cabildo, concejo o ayuntamiento era una institución de gobierno de villas y ciudades. Se encargaba de la administración de los recursos locales y de regular la vida económica de su respectiva comunidad. Era también un tribunal de justicia de instancia menor, civil y criminal. Además, encarnaba la personalidad jurídica de su localidad y tenía jurisdicción sobre un amplio espacio — conocido como los «términos»— que podía albergar a aldeas y áreas rurales. Tal fue su importancia durante la Conquista, que el avance real en los territorios americanos puede medirse a partir del establecimiento de instituciones y funcionarios reales, como los tribunales de justicia o los corregimientos, que mermaron las funciones de los primeros ayuntamientos.

\section{LOS LIBROS DE CABILDO Y SU CONSERVACIÓN}

Debido a esta centralidad administrativa, los concejos produjeron en su actividad diaria una variada documentación — libros de registro de vecinos y predios, libros que agrupaban las misivas con diversas autoridades, ordenanzas, papeles judiciales, entre otros — de la cual solo se ha conservado una ínfima porción. ${ }^{1}$ De entre ellas, la fuente más conocida es los libros de cabildo, formados por el conjunto de las actas de las sesiones que realizaban los miembros de la institución. En cada una de ellas, el escribano designado dejaba constancia de quiénes habían estado presentes, las materias discutidas, los pareceres emitidos y la decisión tomada. Así, ofrecen abundante información sobre los más variados aspectos de la temprana sociedad colonial, tales como la organización

1 Para hacerse una idea del amplio corpus documental que un cabildo como el de Lima albergaba entre sus fondos a mediados de la década de 1550 , véase el «Inventario de los procesos y escrituras del oficio público de Martín Diego Gutiérrez, escribano público y de cabildo de la ciudad de Los Reyes», Los Reyes, ca. 1556, Archivo General de la Nación del Perú [en adelante AGN], Real Audiencia, Causas Civiles del siglo XVI, legajo 1 , cuaderno 3 . 
de las villas y ciudades, el manejo de los recursos locales o las relaciones políticas con diversos actores.

Por su carácter testimonial e importancia administrativa, no es casual que estos libros hayan tenido mejor suerte en conservarse que otros grupos documentales. Por ejemplo, cuando el 8 de junio de 1692, en la ciudad de México, la población amotinada por la carestía de bastimentos incendió las casas del concejo urbano, Carlos de Sigüenza y Góngora, polímata novohispano, consciente de la importancia de los papeles allí conservados, se arrojó a salvarlos del fuego. Desde lo alto del local consistorial, Sigüenza arrojó al primer nivel, a las manos de ayudantes inesperados, la documentación que pudo rescatar. Él mismo dejaría constancia de puño y letra de esta labor al final del primer libro de la ciudad: «Don Carlos de Sigüenza y Góngora [...] libró este libro y los que le siguen del fuego en que perecieron los Archivos de esta cibdad, la noche del día 8 de junio de 1692 en que por falta de bastimento se amotinó la plebe y quemó el Palacio Real y Casas de Cabildo». ${ }^{2}$

No menos conocida es la historia de los libros del Ayuntamiento de Lima durante la ocupación chilena en los años de la Guerra del Pacífico. En 1881, ante la inminente llegada de las tropas invasoras a la capital peruana, el alcalde César Canevaro trasladó, entre diversos documentos, los libros de actas fuera del local municipal; así, los salvó del expolio documental que sufrirían otros archivos y bibliotecas. ${ }^{3}$ De esta manera, gracias a su conservación e importancia, los libros de los concejos ocuparían, llegado el momento, un lugar importante en la edición de fuentes documentales para las historias nacionales de América latina.

\section{EL CUATRICENTENARIO Y SU PUBLICACIÓN SISTEMÁTICA}

El momento cumbre de la publicación de los tempranos libros de cabildo en Hispanoamérica fue el periodo comprendido entre las décadas de 1920 y 1940, durante las cuales se celebró el cuatricentenario de la fundación

2 La cita y la narración de estos acontecimientos han sido tomadas de Carrera 1951: 116-117.

3 Véanse los documentos publicados en Gutiérrez 1990. 
española de las principales ciudades del continente. Aunque algunas de ellas, como México y Lima, editaron sus primeros libros de actas en el último tercio del siglo XIX, fue durante las décadas citadas que se realizó un esfuerzo sistemático y sostenido en esta tarea. ${ }^{4}$ En todos los casos, se priorizó siempre la edición de los libros fundacionales o de los más tempranos que se tenían, labor que fue desarrollada la mayoría de las veces por los propios órganos municipales. ${ }^{5}$

Por medio de este esfuerzo editorial y de un conjunto de actividades conmemorativas, los diversos municipios americanos buscaron inscribir la historia de sus respectivas comunidades en el origen mismo de las historias nacionales e incluso continentales. Con este ánimo, José Rumazo, transcriptor de los dos primeros libros del Concejo de Quito, expresaba con orgullo su publicación «el año cuatro veces centenario del establecimiento de la colonia española en el Quito», pues así se «inicia la conmemoración de la gesta ofreciendo al público estos documentos, por quererlo así el ilustre Cabildo de esta ciudad, la primera fundación de todas las que llegaron a capitales de Estado Sud-americana». ${ }^{6}$ Incluso aquellas ciudades de fundación tardía, como Medellín, o las que no contaban con sus actas más tempranas, como La Habana, aprovecharon esta coyuntura para reafirmar su lugar en la historia de sus respectivos países. ${ }^{7}$

En el Perú, esta empresa tuvo un desarrollo desigual. El esfuerzo más sostenido fue el realizado por el Concejo Provincial de Lima, que solo en 1935 publicó los libros que abarcaban los años comprendidos entre 1535 y $1574 .{ }^{8}$ Un ejemplo similar, pero de menor alcance, fue desarrollado por el Concejo Provincial de Piura en 1939. Al no contar con su libro fundacional, decidió publicar el más antiguo de su posesión, que

${ }^{4}$ El primer libro de actas de Lima fue publicado a fines del siglo XIX (Torres Saldamando 1900). Sobre las primeras ediciones de los libros de la ciudad de México, véase Carrera 1951: 118-127.

${ }^{5}$ Un listado de las publicaciones de libros de acuerdos realizadas hasta mediados del siglo XX se encuentra en Millares 1951.

6 Rumazo 1934a, I: xi.

7 Para las ediciones los libros de actas de Medellín y La Habana, véase Millares 1951: 205 y 207-209, respectivamente.

${ }^{8}$ Lee y Bromley 1935-1962, I, III, IV, V, VI y VII. 
conservaba las actas de los años 1737 y 1738, para así «contribuir, con nuestro modesto, pero entusiástico esfuerzo, a desvelar la pasada existencia de la venerable y cuatro veces secular ciudad de San Miguel». ${ }^{9}$ En otras ciudades como Cuzco, Huamanga o Chachapoyas, los primeros libros capitulares no pudieron ver la luz editorial debido a la sustracción de los originales. Estos terminaron en repositorios norteamericanos debido al tráfico documental de fines del siglo XIX y comienzos del XX. ${ }^{10}$ Sería recién en las décadas siguientes que Raúl Rivera Serna publicaría transcripciones de estos textos luego de acceder a los originales o copias de ellos. Con todo, para mediados de la década de 1970, el corpus de los libros capitulares editados que abarcaban los años del periodo de Conquista del Perú era considerable (véase el cuadro 1).

Cuadro 1. Relación de libros de cabildo de la gobernación de Nueva Castilla y virreinato del Perú del periodo de Conquista publicados hasta la década de 1970

\begin{tabular}{lcl}
\hline Ciudad & Año de fundación & Actas publicadas \\
\hline Quito & 1534 & $1534-1552$ \\
Cuzco & 1534 & $1534-1535$ y $1545-1552$ \\
Jauja & 1534 & 1534 \\
Lima & 1535 & $1535-1539,1544-1546$ y \\
Chachapoyas & 1538 & $1548-1552$ \\
Huamanga & 1539 & $1538-1545$ \\
Arequipa & 1540 & $1539-1547$ \\
\hline
\end{tabular}

Fuentes: Cornejo 1958; Covarrubias 1963; Lee y Bromley 1935-1962, I, III, IV; Málaga y otros 1974; Rivera Serna 1955, 1956-1957, 1965 y 1966; Rumazo 1934a y 1934b; y Torres Saldamando 1900 .

\footnotetext{
9 Vegas 1939.

${ }^{10}$ Los originales de los primeros libros capitulares de Chachapoyas y Huamanga se encuentran en la Harkness Collection, en la Biblioteca del Congreso de Estados Unidos de Norteamérica; el primer libro cuzqueño, en Nueva York, en la Pierpont Morgan Library.
} 


\section{LOS LÍMITES DE SU EMPLEO HISTORIOGRÁFICO}

A pesar de esta disponibilidad, el uso que los historiadores han hecho de los libros de cabildo para la comprensión de la temprana sociedad colonial ha adolecido de una serie de limitaciones. La primera de ellas ha sido la poca crítica documental realizada a esta fuente, lo que ha tenido como consecuencia la permanencia de ciertos mitos historiográficos. El más famoso de estos tópicos es la supuesta pérdida intencionada de algunos libros capitulares durante las guerras civiles entre los conquistadores para evitar responsabilidades judiciales de los involucrados. De ellos, el caso más citado es la desaparición del segundo libro de actas del Concejo limeño (1539-1544) por comprometer a los involucrados en el levantamiento de Diego de Almagro, el Mozo.

Las pocas alusiones a este libro durante los siglos XVIII y XIX solo dan cuenta de su pérdida sin indicar motivo alguno. En las noticias que Ambrosio Cerdán de Landa dio sobre el particular en 1794, solo indica que «es sensible ciertamente falte, ó no haya podido recobrarse hasta ahora el tomo $2 »{ }^{11}$ De la misma manera, Torres Saldamando, en 1888, menciona escuetamente que el libro en cuestión estaba perdido; más aún, da cuenta del uso que fray Juan Meléndez hizo del mismo para la elaboración de sus Tesoros Verdaderos de las Indias, publicados entre 1681 y 1682 , donde se cita explícitamente un acta del segundo libro de la ciudad. ${ }^{12}$ En realidad, la noticia de la supuesta pérdida se originó ya entrado el siglo XX, durante las celebraciones del cuarto centenario de la fundación de Lima.

Fue José de la Riva-Agüero, en 1935, el primero en sugerir, aunque con reservas, la desaparición premeditada de este libro por parte de los participantes de las guerras civiles, pues admitía la posibilidad de un extravío casual en el siglo XVII. ${ }^{13}$ Menos cauto, Raúl Porras afirmaba sin reserva alguna, ya en 1954, que las actas del Cabildo limeño correspondientes

11 Cerdán de Landa 1794, X: 237.

12 Torres Saldamando 1900, II: 228-229. La transcripción de dicha acta se encuentra en Meléndez 1681-1682, I: 104.

13 Riva-Agüero 1935: ix. 
a los ańos 1541-1543 desaparecieron "por contener testimonios sobre la rebelión de los vecinos de Lima con Almagro el Mozo y contra el gobernador Pizarro». ${ }^{14}$ Así, lo que inicialmente se consignó como una posibilidad para explicar la falta de actas en los citados años se convirtió, con el paso del tiempo, en una afirmación repetida por historiadores y comentaristas. En ningún caso se presentó respaldo documental alguno para sustentar la supuesta intencionalidad detrás de su desaparición.

En realidad, el segundo libro de cabildo de Lima no desapareció durante las guerras civiles ni a raíz de la persecución a los inculpados en ellas. En 1556, Diego Gutiérrez, por entonces escribano del Concejo limeño, realizó un inventario detallado de todos los papeles de la institución que tenía en su poder, entre ellos los libros capitulares. ${ }^{15}$ En este documento se consigna la fecha de inicio y fin de cada libro, lo que permite realizar una comparación con los libros conservados en el Archivo Histórico de la Municipalidad de Lima, publicados en 1935.

Según se puede apreciar en el cuadro 2, el segundo libro aún se conservaba en 1556, así como la totalidad de las actas de los años de la rebelión de Gonzalo Pizarro. Es decir, aún después del gobierno de Pedro de la Gasca y de la persecución de los asesinos de Pizarro y de los participantes de la citada rebelión, las actas que comprometían a los involucrados reposaban tranquilamente en la ciudad. ${ }^{16}$ El inventario de los papeles del escribano Gutiérrez muestra que con el tiempo no solo se perdió el segundo libro, sino también el cuarto (1545-1548). ${ }^{17}$ Como

14 Porras 1954: 219.

15 «Inventario», AGN, Real Audiencia, Causas Civiles del siglo XVI, legajo 1, cuaderno 3, f. 121r. Agradezco a Renzo Honores la información sobre el contexto de producción de este documento.

${ }^{16}$ Otro elemento en favor de la desaparición casual del segundo libro de cabildo limeño es el hecho de que las actas de su par cuzqueño de los años de la rebelión, en los que constan las sesiones realizadas tanto por el bando insurgente como por el realista, y por ello sumamente comprometedores, nunca desaparecieron. Estas actas se encuentran publicadas en Cornejo 1958.

${ }^{17} \mathrm{La}$ información ofrecida en el «Inventario» del periodo que comprendería este libro no es clara: "Otro libro de cabildo que pasó antel dicho Diego Gutierres e Pedro de Salinas escribanos numerado en 185 hojas que enpieça a 8 días del mes de mil [sic] dxlv años y 
resultado, la numeración utilizada tanto en las publicaciones como en el Archivo de la Municipalidad está equivocada, pues nunca se cayó en cuenta de la pérdida del cuarto libro. ${ }^{18}$ Con todo, los problemas en el manejo historiográfico de los libros de actas no residen únicamente en la asunción de tópicos cuestionables sobre su existencia y conservación, sino también en el uso que se ha hecho de ellos.

Cuadro 2. Comparación de los libros de cabildo de Lima publicados por Bertram Lee y Juan Bromley (1935-1962) con la información ofrecida por el inventario de papeles de Diego Gutiérrez (1556)

\begin{tabular}{llrr}
\hline \multicolumn{2}{c}{ Libro de cabildo de Lima } & Lee y Bromley & Inventario de 1556 \\
\hline \multirow{2}{*}{ Primero } & Inicio & 17.XI.1534 & $17 . I .1535$ \\
& Fin & 04.II.1539 & $04 . I I .1539$ \\
\hline \multirow{2}{*}{ Segundo } & Inicio & Perdido & $03 . X I .1539$ \\
& Fin & Perdido & $12 . V .1542$ \\
\hline \multirow{2}{*}{ Tercero } & Inicio & 04.I.1544 & $04 . I .1544$ \\
& Fin & 06.I.1546 & 04.V.1546 \\
\hline \multirow{2}{*}{ Cuarto } & Inicio & 12.X.1548 & 08.[en blanco].1545 \\
& Fin & 14.IV.1553 & 05.X.1548 \\
\hline \multirow{2}{*}{ Quinto } & Inicio & 21.V.1553 & 12.X.1548 \\
& Fin & 03.XII.1557 & 14.IV.1553 \\
\hline
\end{tabular}

Fuentes: Lee y Bromely 1935-1962, I, III, IV y V; y AGN, Real Audiencia, Causas Civiles del siglo XVI, legajo 1, cuaderno 3, f. 131r.

Así, una segunda limitación en el aprovechamiento de esta fuente ha sido la concepción tradicional de su utilidad. En primer lugar, tal y como lo concibieron las personas involucradas en su publicación, se ha privilegiado la información administrativa contenida en estas actas.

acabó a 5 días del mes octubre de mil dxlviii años» («Inventario», AGN, Real Audiencia, Causas Civiles del siglo XVI, legajo 1, cuaderno 3).

18 Este error se puede percibir en algunos libros tempranos. Por ejemplo, en la actual numeración, el sétimo libro corresponde a los ańos 1570-1574; sin embargo, al inicio del mismo se puede leer «Libro $8^{\circ}$ de 1570-1574» (Lee y Bromley 1935-1962, VII: 7). 
En 1935, tanto Bertram Lee, transcriptor de los primeros libros de cabildo de Lima, como Diómedes Arias, presidente de la Comisión del IV Centenario de la Fundación de esta ciudad, concebían que el principal valor de esta fuente residía en contener «la verdadera historia administrativa de la ciudad en su periodo de formación». ${ }^{19}$ Esta visión ha guiado la realización de una serie de trabajos sobre diversos aspectos de la temprana organización de la ciudad caracterizados por su especificidad y por tener una visión localista del desarrollo urbano centrada solo en una villa o ciudad particular. ${ }^{20}$

Asimismo, los investigadores han considerado los libros capitulares como un repositorio de datos. Rumazo, por ejemplo, estimaba que el primer libro quiteño serviría a los historiadores para «complementar sus estudios y referencias, corroborando o rectificando las afirmaciones de los cronistas de Indias». ${ }^{21}$ Por su parte, Riva-Agüero evaluaba el atractivo de las actas limeñas en las «infinitas curiosidades» que ofrecían, tales como "precauciones higiénicas y cuarentenas contra las pestes [...] las guerras contra el Turco [...] y los aprestos de Armadas contra Isabel de Inglaterra y contra los suçesivos corsarios». ${ }^{22}$ De esta manera, la historiografía ha privilegiado el uso de la información administrativa y episódica de los libros capitulares, y se ha centrado en la reconstrucción de las historias locales de los primeros poblados del territorio. Además, ha dejado de lado el ámbito político de la institución y la información que las actas de sesiones pueden ofrecer al respecto. Como consecuencia, el análisis del rol político que el conjunto de los cabildos desempeñó en el marco mayor

${ }^{19}$ Lee y Bromley 1935-1962, I: v y vii.

${ }^{20}$ Por ejemplo, Longhurts 1951, Moya 1985 y Morote Best 1975. Para dos trabajos de corte monográfico sobre la institución en la América y el Perú colonial elaborados a partir del uso sistemático de libros de cabildo, véanse Bayle 1952 y Moore 1954 y 1966. Fuera del marco cronológico de esta nota, la potencialidad de esta fuente para reconstruir, a lo largo de casi dos siglos, un aspecto central de la vida urbana como el manejo del agua se encuentra en Bell 2013. Los trabajos reunidos en Gutiérrez 2005 también muestran esta utilidad.

${ }^{21}$ Rumazo 1934a: xxv-xxvi.

${ }^{22}$ Riva-Agüero 1935: x. 
de la gobernación de Nueva Castilla y el virreinato del Perú durante las décadas de 1530 y 1540 ha permanecido ignorado. ${ }^{23}$

Un motivo capital para comprender el poco interés en el ámbito político de la institución se debe a las visiones del periodo de Conquista. Esta etapa es usualmente considerada como una marcada por la guerra, la inestabilidad y la ausencia de orden. Así, solo podría hablarse de la construcción de un orden político a partir del establecimiento del Estado colonial en 1548 luego de la derrota de la rebelión de Gonzalo Pizarro. En pocas palabras, esta visión ofrece una lectura centrada en el desarrollo del Estado —o en términos historiográficos más modernos, de la administración real一, por lo que todo lo anterior es visto en términos de ausencia. Por ello, no es casual que los trabajos sobre la administración y el gobierno del territorio se enfoquen en la décadas de 1550 y 1560 , y no antes. ${ }^{24}$ En este sentido, han sido los presupuestos teóricos de las investigaciones los que han determinado, primero, el marco temporal de la respuesta acerca de cuándo se organizó el gobierno del Perú (luego de 1548, cuando los ayuntamientos vieron disminuida muchas de sus atribuciones) y, segundo, las fuentes a utilizar para responder esta interrogante (básicamente, documentación administrativa vinculada a los virreyes, las audiencias y el Consejo de Indias).

Aún en los casos en los que los investigadores han reconocido la existencia de un primer orden colonial — como James Lockhart, en su trabajo sobre los conquistadores presentes en la captura del inca en Cajamarca, y Rafael Varón, en su estudio sobre la dinámica económica de la empresa del clan Pizarro en la conquista del Perú-, las perspectivas de sus investigaciones han determinado el uso limitado de las actas de sesiones de concejo. ${ }^{25}$ Tanto Lockhart como Varón han centrado sus análisis en la figura de Pizarro, por lo que el examen del rol de los cabildos durante las décadas de 1530 y 1540 tiene un papel secundario. A lo sumo, se ha reconocido que, en sus primeros años de existencia,

\footnotetext{
${ }^{23}$ Un reciente estudio de este rol se encuentra en Alarcón Olivos 2017.

${ }^{24}$ Por ejemplo, Bakewell 1989.

${ }^{25}$ Lockhart 1986-1987 y Varón 1996.
} 
algunos ayuntamientos, como los de Cuzco y Lima, estuvieron copados por personajes del entorno pizarrista.

Asimismo, ambos autores solo se ocupan del gobierno del Perú hasta 1541, año del asesinato del líder extremeño, mucho antes de que la Corona ingresase al territorio y estableciese un nuevo orden político. En consecuencia, estas investigaciones dejan de lado el papel de los diversos caudillos y conquistadores en la instauración de un gobierno hispano y el análisis de los límites del dominio pizarrista. Así, la comprensión de la temprana historia política del Perú se ha visto afectada tanto por una visión teleológica centrada en el desarrollo del Estado como por otra que privilegia el estudio del papel de Pizarro frente al de otros actores.

\section{VALOR Y UTILIDAD DE SU USO SISTEMÁTICO}

El análisis del rol político de los cabildos durante el periodo de Conquista basado en el estudio sistemático de sus libros de actas sirve de correctivo a estas visiones sesgadas. Este cambio de perspectiva se justifica en la centralidad administrativa y política de la institución durante aquellos años: los ayuntamientos de las tempranas villas y ciudades tuvieron un vínculo especial con los diversos actores políticos de la época - los jefes de conquista, el resto de expedicionarios y la Corona-, cada uno de los cuales trató de aprovecharse de ellos para llevar adelante sus propósitos particulares. En este sentido, el uso sistemático de los libros capitulares permite resituar la importancia de los proyectos políticos de los distintos actores de la época y conocer la estructura y funcionamiento del gobierno del Perú antes de la instauración del poder real.

Un temprano desencuentro entre Pizarro y el Concejo de Cuzco, en 1534, reconstruido a partir del libro de actas de dicha ciudad, sirve para ilustrar la utilidad de este tipo documental. La fundación española del Cuzco se realizó el 23 de marzo de 1534 por mano de Pizarro. Al día siguiente, luego de señalados los límites y términos de la ciudad y del registro de los vecinos, el propio gobernador designó la composición del Concejo: por alcaldes nombró a Beltrán de Castro y a su compañero Pedro de Candia; por regidores, entre otros, a sus hermanos Juan y 
Gonzalo Pizarro y a su criado Juan de Valdivieso. ${ }^{26}$ Algunos días después, partió de la ciudad por las noticias de alteraciones por parte de las tropas incaicas. Antes, dejó por teniente de gobernador al alcalde Castro y promulgó algunas ordenanzas para el gobierno de la ciudad, entre ellas, la prohibición de requerir oro, plata, ropa ni cosa alguna a los indios. ${ }^{27}$

La controversia se inició a raíz del incumplimiento de esta disposición. El 5 de julio, Juan de Quincoces, por entonces regidor de Jauja, se presentó con una provisión e instrucción del gobernador ante el Concejo cuzqueño. ${ }^{28}$ Pizarro lo había nombrado juez de comisión para recabar el oro y la plata que se encontraba en la ciudad imperial. También había ordenado que los capitulares entregasen al alguacil mayor todos los indios que estuviesen presos «sobre el sacar del oro», entre ellos Vila Oma, el gran sacerdote inca.

El alcalde Beltrán de Castro y los regidores Pedro del Barco y Francisco Mejía, los únicos presentes en el Concejo ese día, ninguno de los cuales era parte del entorno íntimo de Pizarro, recibieron la provisión; no obstante, establecieron algunas restricciones a su cumplimiento. En primer lugar, dispusieron que Quincoces debía consultar con ellos la ejecución de cada punto de lo que el gobernador le había encargado. Asimismo, el enviado de Pizarro debía actuar teniendo en consideración el «bien e sustentación» del Cuzco y no el de los vecinos de Jauja. Según el alcalde y los regidores, al contar Cuzco con un Cabildo, «de qyen se puede confiar su real servicio», ningún vecino ni regidor de otra ciudad debía entender en los asuntos que concerniesen en materias de justicia, tanto de españoles como de indios, "pues sus mercedes [los alcaldes $y$ regidores] an jurado por el bien e pro comun desta dicha cibdad del Cuzco e no los vecinos ny rejidores de la dicha cibdad de Xauxa».

${ }^{26}$ Beltrán de Castro había sido alcalde de la efímera villa de Bruselas, en Castilla del Oro, actual Costa Rica, en 1527 (Esgueva 2007: 40). Quizá por esta experiencia en el cargo, Pizarro decidió nombrarlo alcalde. La referencia de Valdivieso como criado de Pizarro se encuentra en Varón 1996: 116.

${ }^{27}$ Lohmann 1986: 149-151.

${ }^{28}$ La mención de Quincoces como regidor de Jauja se encuentra en Lohmann 1986: 334. 
Por último, y en tono más desafiante, declaraban que el oro y la plata eran propiedad de los vecinos. Todo aquello que se recolectara no sería sacado de la ciudad, sino que se depositaría en la casa de uno de ellos hasta que el gobernador dispusiese a quién debía ser entregado. ${ }^{29}$

Impedido de realizar su cometido, Quincoces informó a Pizarro la resistencia que encontró de parte de los capitulares cuzqueños. Cerca de dos semanas después, el 23 de julio, el gobernador redactó desde Jauja una carta dirigida a su lugarteniente, al Cabildo y a los vecinos de Cuzco en la que señalaba que había sido informado de los impedimentos puestos a su enviado. En un tono severo, les ordenaba que cumpliesen su provisión anterior «so pena de la vida y perdymyento de todos vuestros bienes». La carta puntualizaba que todos debían declarar cualquier información referente a la existencia de oro o plata en la ciudad. Si alguien hubiese cogido algo, debía entregarlo. Asimismo, Beltrán de Castro, lugarteniente y alcalde al mismo tiempo, debía liberar a los indios presos por los rescates de oro al alguacil mayor. Por último, Quincoces quedaba excusado de realizar sus acciones en coordinación con el lugarteniente y el Concejo; solo debía hacerlas ante el veedor, un testigo y un escribano. ${ }^{30}$

Unos días después, el 4 de agosto, en una sesión convocada a pedido de Quincoces, la carta fue leída a los alcaldes, regidores y algunos vecinos que estuvieron presentes. En su respuesta consignada en el acta de la sesión, el Cabildo afirmaba que había cumplido y obedecido la anterior provisión del gobernador. Si había puesto algún reparo, fue por esperar que Pizarro declarase a quién le pertenecían los ricos metales, ya que, según reafirmaban, eran propiedad de los vecinos. A pesar de este alegato, accedían a cumplir lo solicitado, aunque bajo una condición: dos procuradores de la ciudad irían a Espańa en resguardo del oro y plata y se los entregarían al rey. ${ }^{31}$

${ }^{29}$ Rivera Serna 1965: 20-21.

${ }^{30}$ Apercibimiento a las autoridades del Cuzco para que no entorpecieran el cumplimiento de las comisiones confiadas a Juan de Quincoces, Jauja, 23 de julio de 1534 (Rivera Serna 1965: 21-22). Este documento también ha sido publicado en Lohmann 1986: 78-79.

${ }^{31}$ Rivera Serna 1965: 21-22. En esta transcripción se consigna erróneamente como fecha de la sesión el 4 de julio de 1534 . 
Las noticias debieron correr como pólvora entre la reducida población española de aquellos años, pues alcaldes y regidores volvieron a reunirse el mismo día, esta vez con 33 vecinos. Se precisó el monto del servicio en aproximadamente 30 mil pesos de oro y 35 mil marcos de plata. Según señalaron los concurrentes, esta cantidad había sido descubierta por los propios vecinos y sus yanaconas. En tono quejumbroso, añadían que luego de fundar Cuzco, Pizarro había partido a Jauja dejando a cargo de los vecinos la guarda y el amparo de la ciudad. Eran ellos quienes «estando en mucho riesgo e aventura por la mucha gente de indios que avia y ellos tan pocos y el socorro tan lejos lo hallaron y descubrieron». ${ }^{32}$ Considerando la decisión de Pizarro como un exceso, el Ayuntamiento acordó apelar al Consejo de Indias "por ser [el mandato] tan riguroso e porque ningun tiempo los vasallos sean molestados». ${ }^{33}$

Tiempo después, Pizarro decidió reafirmar su dominio sobre la ciudad. Primero, aseguró los nombramientos de teniente de gobernador y de capitán general en personas de su entorno cercano. Hernando de Soto obtuvo el primero de estos cargos y rápidamente ejerció un marcado ascendiente en las sesiones y decisiones del Cabildo. ${ }^{34}$ Incluso llegó a encarcelar al obstinado alcalde Castro a fines de diciembre por una discrepancia de carácter administrativo que derivó hacia aspectos personales. En aquella ocasión, aunque Castro indicó que apelaría su carcelería, «el dicho señor teniente dixo que le mandava e mandó lo que mandado tiene nostante su apelación por cuanto aquí no tiene superior el dicho teniente». ${ }^{35}$ Quedaba clara la primacía del representante del gobernador

\footnotetext{
32 Rivera Serna 1965: 28.

${ }^{33}$ Rivera Serna 1965: 22. El desencuentro entre Pizarro y el Concejo cuzqueño es mencionado en el testimonio de Gerónimo de Aliaga, contador en Jauja en esta época, proporcionado por el obispo de Tierra Firme fray Tomás de Berlanga para la información secreta tomada en Lima en 1535 (Pacheco, Cárdenas y Torres de Mendoza, 1864-1884, $\mathrm{X:}$ 246-249).

${ }^{34}$ De Soto fue recibido como teniente de gobernador por el Cabildo de Cuzco el 25 de agosto de 1534 (Rivera Serna 1965: 29). Las instrucciones que Pizarro le dio para este cargo se encuentran en Lohmann 1986: 79-80. Para el control que De Soto ejerció sobre la institución, véase Rivera Serna 1965: 29-30, 31, 32 y 38.

${ }^{35}$ Rivera Serna 1965: 40.
} 
sobre el Concejo. Tres días después de la llegada de De Soto, el 28 de agosto de 1534, Juan Pizarro, hermano del gobernador, fue recibido por teniente de capitán general de la ciudad. ${ }^{36}$ Para asegurar un mayor control, el año siguiente Pizarro nombró a su criado Quincoces como regidor y a su hermano Hernando como teniente de gobernador. ${ }^{37} \mathrm{~A}$ lo largo de los ańos, el mayor de los Pizarro mantuvo el Cuzco en manos cercanas. Por ejemplo, en 1539, Antonio de la Gama, su hombre de confianza, sería su teniente en esta ciudad.

Por último, Pizarro se encargó de ofrecer a la Corona una imagen negativa y distorsionada del proceder de los vecinos cuzqueños. Entre otras comisiones encargadas a De Soto, se encontraba la de realizar una información secreta de las personas que hubiesen tomado oro y plata contra su mandato "para que yo lo vea e haga lo que fuere justicia». ${ }^{38} \mathrm{En}$ noviembre de 1535 , el futuro marqués escribió al soberano indicándole que cuando quiso tomar algunas joyas del reparto del Cuzco para obsequiarlas a su majestad, los vecinos «me lo contradixeron y [...] se pusieron en me lo resystir». Añadía que la parte del donativo que había sido recabado "yo las halle que no de la suya dellos pues nunca para semejante servicio tuuyeron voluntad». ${ }^{39}$ Un año después, el 13 de noviembre de 1536, cuestionado por el obispo de Tierra Firme, fray Tomás de Berlanga, quien había realizado una información secreta contra él y los oficiales reales sobre el manejo de la Real Hacienda, reiteró estos argumentos: el servicio de los vecinos del Cuzco "fue cautelosa e maliçiosamente hecho», pues no tenían derecho alguno sobre el oro y la plata, que «yo lo uve e hize buscar»; además, nunca habían tenido voluntad de hacer algún donativo a la Corona. ${ }^{40}$ No obstante, cuando el 9 de enero de 1538 , fue apremiado por los oficiales reales para entregar el monto del donativo, Pizarro respondió que lo había utilizado en gastos militares, aunque en

36 Ib.: 29.

${ }^{37}$ Ib.: 20 y 43 .

${ }^{38}$ Lohmann 1986: 79.

${ }^{39}$ Ib.: 46-47.

${ }^{40}$ Ib.: 207. 
realidad había servido para pagarle a Pedro de Alvarado la transferencia de su armada y gente. ${ }^{41}$

¿Cómo entender el proceder del Cabildo cuzqueño en este caso? La explicación reside en el surgimiento de intereses locales. Aunque en otras villas y ciudades este proceso tomaría algo más de tiempo hasta que los recursos económicos comenzasen a ser explotados, en el caso de la ciudad imperial este temprano desarrollo se debió a la disponibilidad inmediata de oro y plata procedentes de los tesoros incas aledaños. Esta situación explica el celo del Concejo y de los vecinos en reclamar para sí estos metales contra los deseos del gobernador, así como su actitud frente a la intromisión de un regidor y vecino de otra ciudad en los asuntos judiciales locales. Con esta experiencia, Pizarro debió sacar en claro que no bastaba con determinar la composición de los ayuntamientos para asegurar su fidelidad, sino que era necesaria la presencia efectiva de personajes de su entorno —ni sus hermanos Juan y Gonzalo ni amigos o criados como Pedro de Candia y Juan de Valdivieso habían estado presentes para apoyar la labor de Quincoces cuando acudió al ayuntamiento por primera vez-. Asimismo, debía prestar mayor cuidado en el nombramiento de sus representantes en el futuro. Castro había actuado más como alcalde y vecino cuzqueño que como teniente de gobernador. Así, si bien este ejemplo muestra la utilidad de los libros de actas para el estudio del surgimiento de los intereses locales y los límites del dominio pizarrista, es importante recordar que su uso sistemático presenta también una serie de dificultades.

\section{LAS LIMITACIONES DE LA FUENTE}

Una dificultad al utilizar los tempranos libros de concejo para comprender la historia política del periodo de Conquista es su desigual conservación. De todas las ciudades fundadas hasta 1548 , solo en el caso de Quito se ha conservado la totalidad de sus libros de actas hasta dicho año. Más que a factores políticos, esta situación se debe al descuido con el que estos libros fueron custodiados. Por ejemplo, en 1602, el procurador general de la ciudad de Quito, Melchor de Castro Macedo,

${ }^{41} \mathrm{Ib} .: 113$ y 336 , nota 1. 
se refería así al estado del primer libro: «Digo que en el archivo de este cabildo está un libro de la fundación de esta ciudad [...] y es ansí que el (dicho) libro esta tan biejo y consumido que está roto y por muchas partes desquadernado». ${ }^{42}$ Esta desigual conservación puede llegar a ser un impedimento infranqueable cuando en algunos casos no se ha conservado ningún libro, como en Puerto Viejo o La Plata. Sin embargo, un reto mayor para el uso sistemático de estas actas reside en la calidad de la información registrada en ellas.

El detalle de lo consignado en cada acta de cabildo variaba de acuerdo con la minuciosidad de cada escribano. Por ejemplo, algunos solo registraban el resultado final de una discusión, mientras que otros ponían por escrito los pareceres individuales de alcaldes y regidores. Esta situación se complica por el hecho de que, dado lo convulso del periodo, existía una alta movilidad entre estos funcionarios, lo que explica que solo en la elaboración de los dos primeros libros de actas de Quito (1534-1551) interviniesen hasta trece de ellos. ${ }^{43} \mathrm{El}$ mejor camino para lidiar con la conservación desigual de los libros de los diversos poblados y con la variación de registro de cada escribano es tener un marco amplio de análisis, no el de ciudades o villas, sino el de toda la gobernación o virreinato. Así, las carencias particulares pueden ser fácilmente sorteadas al trabajar con el corpus completo de todos los libros existentes del periodo.

Una última dificultad en el uso de los libros de cabildo reside en la pérdida del contexto documental en el que esta fuente tenía sentido originalmente. Como se ha mencionado, los ayuntamientos produjeron un amplio corpus de documentos, del cual los libros de actas constituyen solo un breve fragmento. Además, los archivos de los concejos albergaron una diversidad de papeles producto de las relaciones con otras instituciones o particulares, como cédulas reales, mandatos del gobernador o misivas. Por ello, es usual que a lo largo de las actas capitulares encontremos información fragmentaria sobre algún pleito judicial del ayuntamiento, las resistencias al establecimiento del cobro de diezmos o el inicio de las

\footnotetext{
${ }^{42}$ Rumazo 1934a, I: 3-4.

${ }^{43}$ Ib.: xii-xiii.
} 
visitas a las encomiendas. La presencia de estas huellas documentales se debe a que, como ha señalado María Luisa Domínguez, los libros capitulares funcionaron como una especie de central documental que, al ser consultada, remitía a otros documentos albergados en los archivos de la institución. Sin embargo, es justamente este carácter indiciario de la información registrada en esta fuente el que mayor provecho puede ofrecer a la investigación, pues la dirige y expande a otros tipos documentales. ${ }^{44}$ De esta manera, se puede profundizar en aspectos sobre los que la fuente guarda silencio.

Uno de los temas sobre el que las actas capitulares ofrecen poca información es los negocios particulares de los alcaldes y regidores, así como los vínculos entre ellos y Pizarro. Los indicios que aparecen en el primer libro de Cabildo de Lima sobre el manejo irregular de los bienes de difuntos por parte de algunos regidores arrojan luces sobre el particular. Hasta mediados del siglo XVI, antes de que se estableciesen juzgados de bienes de difuntos en Indias, la custodia de estos fondos, en tanto fuesen finalmente recibidos por sus respectivos herederos, estaba a cargo de la justicia ordinaria (un alcalde), un regidor y el escribano del cabildo del lugar donde hubiese sucedido el deceso. Ellos eran los encargados de recabar estas pertenencias, inventariarlas, venderlas eventualmente en almoneda y hacer llegar lo procedido a sus beneficiarios. ${ }^{45}$ En un lugar como el Perú de las décadas de 1530 y 1540, donde conquistadores, mercaderes, clérigos y funcionarios adquirían fabulosas fortunas por medios no siempre lícitos, y la muerte era un riesgo diario, estos bienes eran una codiciada fuente de ingresos, entre otros, por los oficiales de la Santa Cruzada que reclamaban para sí las pertenencias de aquellos muertos en el territorio sin haber dejado testamento. ${ }^{46}$ Era usual, además, que los gobernadores o adelantados echasen mano continuamente de ellos para financiar sus propias empresas comerciales y de conquista.

\footnotetext{
${ }^{44}$ Domínguez 2017.

45 Para un panorama del desarrollo de los juzgados de bienes de difuntos en Indias, véase Soberanes 2008; la primera mitad del estudio de García 2010 ofrece una visión general para el siglo XVI.

${ }^{46}$ Porras 1944-1948, II: 364.
} 
Al menos desde 1526, la Corona había establecido con detalle una serie de medidas para prevenir sus malos manejos y aprovechamiento ilícito. Entre las prácticas que se esperaba combatir se encontraban la omisión de bienes «de mucho valor» en los inventarios, su venta a precios menores que los reales, el poco cuidado en el cobro de las deudas de los difuntos y los pagos a dudosos acreedores. Además, los registros que los tenedores enviaban a la Casa de Contratación eran imprecisos sobre la identidad de los difuntos, lo que dificultaba localizar a los herederos; el motivo detrás de este descuido era el beneficio que recibían del décimo - e incluso el quinto- de los bienes que se declaraban por perdidos. ${ }^{47}$ Entre los elementos indiciarios que uno puede encontrar sobre el manejo irregular de estos fondos en el primer libro de cabildo de Lima, se encuentran la presencia a lo largo de los años de un socio empresarial de Pizarro en su administración, el veedor García de Salcedo; el poco cuidado en la toma de cuentas anuales a los tenedores de bienes; y la noticia de una provisión real para mejorar el manejo de estos fondos en el Perú. ${ }^{48}$ A partir de estos rastros documentales, el hilo de la madeja nos conduce a descubrir que Pizarro se aprovechó sistemáticamente de estos fondos a lo largo de los años y que para ello contó con el apoyo de Salcedo, a quien protegió de las averiguaciones por estos malos manejos.

La historia del manejo truculento de estos fondos se inicia en mayo de 1533, en Cajamarca, un mes antes del reparto del rescate de Atahualpa, cuando el futuro marqués designó, provechosamente, a Hernán González por tenedor de bienes de los difuntos ab intestato. ${ }^{49}$ Este nombramiento fue irregular, pues en principio debió realizarse por el Concejo de San

${ }^{47}$ Colección de documentos inéditos 1895-1932, IX: 261-267.

${ }^{48}$ Lee y Bromley 1935-1962, I: 128-129, 131 y 278. Para la relación empresarial entre Pizarro y Salcedo, véase Varón 1996: 311-313 y 405-410. También puede revisarse el finiquito de compañía entre el veedor y Cristóbal de Burgos, en nombre de Francisca Pizarro, con poder de su padre, Los Reyes, 21 de mayo de 1538, AGN, Protocolos Notariales, 18, 1537-1538, f. 532r-v. En este documento, Salcedo declara que «yo el dicho veedor meti en ella [la compañía] todas mis granjerias e la dicha dońa Francisca seys mil pesos de oro de ley perfecta». La ganancia de la compañía fue de 13 mil pesos de oro.

${ }^{49}$ Lohmann 1986: 73-74. 
Miguel, cuyos miembros eran los encargados de velar por estos fondos. $\mathrm{Al}$ año siguiente, Pizarro ordenó que los tenedores de bienes de difuntos del Concejo de Jauja, uno de los cuales era Salcedo, pusiesen a disposición de su criado Pedro Navarro, encargado de la recepción de sus mercaderías procedentes de Panamá, 40 mil pesos de oro que serían devueltos cuando se lo requiriesen. ${ }^{50}$ De aquí en adelante, gracias a su regiduría en Lima, el veedor sería recurrente tenedor de bienes en esta ciudad. ${ }^{51}$

Pizarro y Salcedo trabajaron en conjunto para aprovecharse de estos fondos. En 1535, la Corona, noticiada probablemente del mal uso que se hacía de ellos, dio instrucciones al obispo fray Tomás de Berlanga, para la reforma de su administración en el Perú - cuyo eco es posible rastrear en las actas de cabildo——. ${ }^{52}$ El obispo debía tomar las cuentas a los administradores pasados y tenía incluso facultad para dejar sin efecto los nombramientos de tenedores que se hubiesen realizado. No obstante, su misión no debió ser exitosa, pues al poco tiempo, en 1537, los tenedores de bienes de difuntos del Cabildo de Lima le tomaron las cuentas al veedor de los bienes que tuvo a su cargo en los años previos. En aquella ocasión, fue alcanzado en 22.729 pesos de oro; al ser instado a pagarlos, Pizarro emitió un auto para que continúen bajo su custodia. ${ }^{53}$

Cuatro años después, en 1541, cuando por comisión real el regidor Rodrigo de Mazuelas volvió a tomarle cuentas, halló que Salcedo, quien había continuado como tenedor, debía 16.022 pesos de oro, 1 grano y 1 tomín. Según lo acusó, el veedor había utilizado estos fondos para sus propios negocios: «es público y notorio que a siete años que resçibió los

${ }^{50}$ Ib.: 80. La referencia de Navarro como criado de Pizarro se encuentra en Varón 1996: 126.

${ }^{51}$ Salcedo fue tenedor de bienes en Jauja en 1534 (Lohmann 1986: 80); en Lima, probablemente en 1535 y, con seguridad, en 1536, 1538 y 1539 (Lee y Bromley 19351962, I: $128-129,131,178,188-189$ y 278). En una ocasión, cuando no ostentaba este cargo, obtuvo poder del tenedor de bienes para cobrar directamente ciertas deudas de un difunto en su favor. Véase el poder para cobrar otorgado por Sebastián de Torres, tenedor de bienes de difuntos, a García de Salcedo, Los Reyes, 14 de enero de 1538, AGN, Protocolos Notariales, 18, 1537-1538, ff. 342v-343v.

${ }^{52}$ Lee y Bromley 1935-1962, I: 131; y Porras 1944-1948, II: 105-109 y 123-124.

${ }^{53}$ Lohmann 1986: 10. 
dichos vienes en oro de quilates y a tratado e contrabtado con ellos e ganado mucha suma de pesos de oro ansí en Espańa como en este reino». Aseguraba, asimismo, que el gobernador lo había favorecido para este fin, pues «trayan sus contrataçiones clara y abiertamente en mucha suma de pesos de oro». ${ }^{54}$ Así, al trabajar con un método indiciario, el problema de la pérdida de contexto documental de los libros capitulares puede servir más bien para profundizar en algunos temas poco visibles en las actas de sesiones, como la colusión entre algunos miembros de la institución con Pizarro y el uso personal de los fondos de bienes de difuntos. De esta manera, se puede obtener un panorama más claro de cuáles fueron los vínculos de alcaldes y regidores con los jefes políticos del territorio.

\section{CONCLUSIONES}

¿Cuál es, entonces, la utilidad del uso sistemático de los libros de cabildo para la historia del establecimiento de un gobierno colonial en el Perú? Este trabajo muestra que el uso sistemático de esta fuente permite una relectura de la temprana historia política del territorio, alternativa a la de una visión centrada en el desarrollo del Estado y a aquella que privilegia el rol organizador de Pizarro. De esta manera, esta fuente es útil para profundizar en el conocimiento de los primeros sistemas administrativos y de gobiernos coloniales. Como el análisis del conflicto entre el gobernador extremeño y el Cabildo cuzqueño muestra, el uso de este corpus documental permite conocer el desarrollo de intereses locales en el seno de los diferentes concejos distintos de aquellos perseguidos por los jefes de conquista. Si bien Pizarro procuró servirse de la institución como parte de las bases de su poder, como otros antes y después de él, rápidamente encontró resistencia.

54 «Rodrigo de Mazuelas, vecino de Lima y thenedor de bienes de difuntos de las provincias del Peru, con Garcia de Salcedo, veedor de s. m. y cobrador que ha sido de dicho bienes de difuntos, sobre las quentas de ellos». Archivo General de Indias [en adelante AGI], Justicia, 395, n. 1. Sobre la comisión real de Mazuelas para recabar estos bienes, véase AGI, Lima, 565, L. 3, ff. 156r-v y 158r-159r. Las actividades comerciales de Salcedo han sido analizadas en Carmona y Acosta 1999, aunque este trabajo no menciona el uso que el veedor hizo de los fondos de bienes de difuntos. 
Así, pues, a pesar de sus limitaciones, que pueden ser aprovechadas en favor de la investigación, el análisis de los libros de actas permite comprobar hasta qué punto los intereses de los conquistadores-vecinos representados en los cabildos fueron coincidentes con los de los líderes de la conquista; conocer a partir de qué momento estos intereses empezaron a divergir; y evaluar los intentos, fallidos o exitosos, para evitar la dispersión del ejercicio del poder y controlar a estas instituciones. Por último, gracias a su empleo, es posible entender las relaciones que tanto los concejos como los caudillos procuraron mantener con la Corona para legitimar su autoridad. En pocas palabras, el uso sistemático de esta fuente permite un mejor conocimiento de la temprana historia política del Perú durante la Conquista y abre el camino para repensar los tempranos órdenes coloniales en otras partes del continente.

\section{BIBLIOGRAFÍA}

Alarcón Olivos, Marcos. 2017. El papel de los cabildos en el primer orden colonial peruano, 1529-1548. Tesis de licenciatura en Historia. Lima: Pontificia Universidad Católica del Perú.

Bakewell, Peter. 1989. «La maduración del gobierno del Perú en la década de 1560». Historia Mexicana. Vol. XXXIX, núm. 1: 41-70.

Bayle, Constantino. 1952. Los cabildos seculares en la América española. Madrid: Sapientia.

Bell, Martha. 2013. The Governance of Food Technology and Environmental Resource Flows: Connecting Mills, Water, Wheat, and People in Colonial Lima, Peru (15351700). Tesis de doctorado en Geografía. Pennsylvania: The Pennsylvania State University.

Carmona, Victoria y Antonio Acosta. 1999. «Real Hacienda y Negocios. García de Salcedo, Oficial Real en Lima (1532-1556)». Jahrbuch für Geschichte Lateinamerikas. Vol. 36: 33-61.

Carrera, Manuel. 1951. «Las actas municipales de la historia de México». En Altamira, Rafael y otros. Contribuciones de la historia municipal de América. México, D. F.: Cultura, 109-135.

Cerdán de Landa, Ambrosio. 1794. «Disertación preliminar a los apuntamientos históricos [...]». Mercurio Peruano. Tomo X, enero-abril: 215-244.

Colección de documentos inéditos relativos al descubrimiento, conquista y organización de las antiguas posesiones españolas de Ultramar. 1895-1932. Segunda serie. Madrid: Real Academia de la Historia, 25 tomos. 
Cornejo, Jorge. 1958. «Actas de los libros de cabildos del Cuzco 1545-1548: rebelión de Gonzalo Pizarro». Revista del Archivo Histórico del Cuzco. Núm. 9: 37-305.

Covarrubias Pozo, Jesús. 1963. Segundo libro de actas: acuerdos, proveimientos, mandatos y ordenanzas de los magnificos señores del cabildo justicia y regimiento de la ciudad del Cuzco. Cuzco: H. G. Rozas.

Domínguez, María Luisa. 2017. «Los libros del Cabildo de Cuzco: un catálogo documental de la Monarquía Hispánica». Ponencia presentada en el XXV Congreso Internacional de la Asociación de Estudios Latinoamericanos (LASA). Lima, 29 de abril.

Esgueva, Antonio (ed.). 2007. Las fronteras de Nicaragua y Costa Rica en los documentos históricos. Managua: Instituto de Historia de Nicaragua y Centro América, y Universidad Centroamericana.

García, María Belén. 2010. «Los Autos de Bienes de Difuntos en Indias. El caso del sevillano Baltasar Tercero». Nuevo Mundo Mundos Nuevos. https://doi. org/10.4000/nuevomundo.59829

Gutiérrez, Laura. 1990. «Sobre la ocupación chilena». Boletín del Instituto RivaAgüero. Núm. 17: 523-532.

. (ed.). 2005. Lima en el siglo XVI. Lima: Pontifica Universidad Católica del Perú e Instituto Riva-Agüero.

Lee, Bertram y Juan Bromley (eds.). 1935-1962. Libros de Cabildos de Lima. Lima: Sanmartí, 23 vols.

Lockhart, James. 1986-1987. Los de Cajamarca: un estudio social y biográfico de los primeros conquistadores del Perú. Lima: Milla Batres, 2 tomos.

Lohmann, Guillermo. 1986. Francisco Pizarro. Testimonio. Documentos oficiales, cartas y escritos varios. Madrid: Consejo Superior de Investigaciones Científicas.

Longhurts, John E. 1951. «Early Price Lists in Lima and a Petition for Redress». The Hispanic American Historical Review. Vol. 31, núm. 1: 141-145. https:// doi.org/10.2307/2509166

Málaga, Alejandro y otros. 1974. Indice del libro Segundo de Actas de Sesiones y Acuerdos de la Ciudad de Arequipa, 1546-1556. Arequipa: Imp. Edit. "El Sol".

Meléndez, Juan. 1681-1682. Tesoros Verdaderos de las Indias. Roma: Imprenta de Nicolas Angel Tinassio, 3 tomos.

Millares, Agustín. 1951. "Notas bibliográficas acerca de archivos municipales, ediciones de libros de acuerdos y colecciones de documentos concejiles». En Altamira, Rafael y otros. Contribuciones de la historia municipal de América. México, D. F.: Cultura, 179-238.

Moore, John Preston. 1954. The Cabildo in Peru under the Hapsburgs: a Study in the Origins and Powers of the Town Council in the Viceroyalty of Peru 1530-1700. Durham: Duke University Press. 
1966. The Cabildo in Peru under the Bourbons: a Study in the Decline and Resurgence of Local Government in the Audiencia of Lima. Durham: Duke University Press.

Morote Best, Efraín. 1975. Huamanga entre 1539 y 1547 (examen del primer libro del cabildo). Lima: Jurídica.

Moya, Frank. 1985. Lima. El Cabildo y la vida local en el siglo XVI (1534-1553). Santo Domingo: Corripio.

Pacheco, Joaquín; Cárdenas, Francisco y Luis Torres de Mendoza. 1864-1884. Colección de documentos inéditos relativos al descubrimiento, conquista y colonización de las posesiones españolas en América y Oceanía. Madrid: Real Academia de la Historia, 42 tomos.

Porras, Raúl. 1954. Fuentes históricas peruanas (apuntes de un curso universitario). Lima: Juan Mejía Baca y P. L. Villanueva. . 1944-1948. Cedulario del Perú: siglos XVI, XVII y XVIII. Lima: Ministerio de Relaciones Exteriores, 2 tomos.

Riva-Agüero, José de la. 1935. «Prólogo». En Concejo Provincial de Lima. Libros de Cabildos de Lima. Lima: Concejo Provincial de Lima, tomo I, ix-xii.

Rivera Serna, Raúl. 1955. «Libro primero de Cabildos de San Juan de la Frontera de Chachapoyas, 1538-1545». Revista Fénix. Núm. 11: 292-330. 1956-1957. «Libro primero de Cabildos de San Juan de la Frontera de Chachapoyas, 1538-1545». Revista Fénix. Núm. 12: 280-336. . 1965. Libro primero de cabildos de la ciudad del Cuzco. Lima: Universidad Nacional Mayor de San Marcos. . 1966. Libro del Cabildo de la ciudad de San Juan de la Frontera de Huamanga, 1539-1547. Lima: Casa de la Cultura del Perú.

Rumazo, José. 1934a. Libro primero de cabildos de Quito. Quito: [Cándido Briz Sánchez, impresor], 2 vols.

. 1934b. Libro segundo de cabildos de Quito. Quito: [Cándido Briz Sánchez, impresor], 2 vols.

Soberanes, José Luis. 2008. «El Juzgado General de Bienes de Difuntos». En Puente, José de la y Jorge Armando Guevara Gil (eds.). Derechos, instituciones y procesos históricos. Lima: Pontificia Universidad Católica del Perú e Instituto Riva-Agüero, vol. I, 401-426.

Torres Saldamando, Enrique. 1900. Libro primero de Cabildos de Lima. París: Impr. Paul Dupont, 3 vols.

Varón, Rafael. 1996. La ilusión del poder: apogeo y decadencia de los Pizarro en la conquista del Perú. Lima: Instituo de Estudios Peruanos e Instituto Francés de Estudios Andinos.

Vegas, Ricardo (ed.). 1939. Libro del Cabildo de la ciudad de San Miguel de Piura: años 1737 a 1748. Piura: Concejo Provincial de Piura. 


\title{
Garcilaso y el caso de la mala muerte del virrey Toledo*
}

\section{Garcilaso and the Case of the Evil Death of Viceroy Toledo}

\author{
CATHERINE JULIEN
}

Western Michigan University

Garcilaso Inca de la Vega concluye el segundo tomo de los Comentarios reales, publicado en 1617, con cinco capítulos que tratan acerca del gobierno de Francisco de Toledo. Este último, virrey del Perú entre 1569 y 1581, fue conocido principalmente por haber realizado la visita general del virreinato que sentó las bases institucionales de la administración espańola que duraría hasta fines de la época colonial. Felipe Guaman Poma de Ayala, autor de la misma época que Garcilaso, identificó algunos aspectos de la reforma toledana como responsables de muchos de los males que plagaban la sociedad andina de su tiempo, en particular la reducción de la población indígena a pueblos de tipo español y la introducción de corregidores. El autor de los Comentarios reales, en cambio, no se interesó en la visita: cuatro de los cinco capítulos que dedica a la época toledana se ocupan de la captura y ajusticiamiento de Topa Amaru en el Cuzco. ${ }^{1}$

* Catherine Julien (1950-2011) dejó este y otros textos en manos de Jeremy Mumford, quien recientemente le hizo llegar esta nota al director de Histórica para su publicación.

${ }^{1}$ Se trata de los capítulos XVI-XX de libro octavo de la Historia general. Uso «Inca» con mayúscula en referencia a Topa Amaru, e «inca» o «incas» para los miembros del grupo mayor.

HISTORIOด XLI.2 (2017): 169-188 / ISSN 0252-8894 
Topa Amaru era el hermano menor de Titu Cusi Yupanqui, el inca que gobernó la provincia autónoma de Vilcabamba entre 1559 y 1570. Fue con él que, en 1565, el licenciado Lope García de Castro - antecesor de Toledo y gobernador del Perú entre 1563 y 1569- negoció unas capitulaciones formales para que el inca aceptase ser vasallo del rey de España e incorporase la provincia de Vilcabamba al Perú de los españoles. ${ }^{2}$ Castro también concedió a Titu Cusi una serie de mercedes para que salga de Vilcabamba. ${ }^{3}$ En ese sentido, aunque las relaciones entre Vilcabamba y el Perú han sido difíciles de desentrañar, podemos aseverar que Toledo prefería abrogar el acuerdo negociado por Castro y confirmado por Felipe II para acabar de una vez con ese vestigio del poder incaico. ${ }^{4}$

Cuando se supo de la muerte de Titu Cusi, el ejército enviado a Vilcabamba para capturarlo tomó preso a su hermano Topa Amaru. Este fue llevado al Cuzco e hizo su entrada el 21 de septiembre de 1572. Después de un proceso criminal y la catequización para que pudiera recibir el bautizo antes de morir, Topa Amaru fue degollado en la plaza de esa misma ciudad el 24 de septiembre de aquel año. En los cuatro capítulos que dedica a este tema en sus Comentarios reales, Garcilaso apenas menciona la campańa militar, pues prefiere contar los eventos que rodearon la muerte del inca.

Junto con esta historia, Garcilaso narra el castigo efectuado por Toledo para con los mestizos «hijos de los conquistadores» del Cuzco por haberse «conjurado con el príncipe Tupac Amaro, y con los demás incas para alzarse con el reino». Menciona el destierro de varios mestizos, incluso a Juan Arias Maldonado, hijo de Diego Maldonado. ${ }^{5}$ Algunos de los incas del Cuzco fueron enjuiciados, por haberse carteado con su pariente en Vilcabamba para convencerlo de que no dejara esa región, ${ }^{6}$ pero es importante señalar que no hubo ningún motín de mestizos durante ese tiempo.

2 Guillén Guillén 1977.

3 Nowack 2006.

4 Julien 2007.

5 Garcilaso 1960: 167.

6 Nowack y Julien 1993. 
Entre los siete acusados en el juicio figuraban algunos de los incas más importantes del Cuzco: don Carlos Inca, el hijo de Paullu Topa; don Diego Cayo, descendiente de Pachacuti que había gobernado Tawantinsuyu en algún momento como teniente de Huayna Capac; y don Alonso Tito Atauchi, hijo de otro inca del mismo nombre, quien tenía a su cargo la propiedad que pertenecía a la panaca de Huayna Capac. Fueron sentenciados al destierro y, después del ajusticiamiento de Topa Amaru y dos de sus capitanes, ellos y algunos de los presos tomados en Vilcabamba salieron caminando a Lima, rumbo al destierro en España. ${ }^{7}$ El motín de mestizos mencionado por Garcilaso tendría que ser aquel que tuvo lugar en 1567, cuando Juan Arias Maldonado fue culpado de participar junto con otros mestizos y algunos cuantos espańoles. ${ }^{8}$ Sin embargo, en 1572 Maldonado estaba en España, siguiendo un pleito con el fiscal. Garcilaso tuvo que haber conocido mejor los detalles del motín, porque el propio Maldonado lo visitó en Montilla dos veces en aquellos años. ${ }^{9}$

A lo mejor Garcilaso estaba equivocado o mal de la memoria. Cuando leemos lo que escribió sobre la época toledana en contraposición de la documentación más contemporánea a los eventos, encontramos muchos errores de este tipo, ya que confunde personas, fechas y eventos. Para ser justos, debemos notar que, en este aspecto, Garcilaso se asemeja a otros autores que escribieron sobre la época de la conquista sin consultar documentación alguna de archivo. ${ }^{10}$ En su época, solamente Antonio de Herrera y Tordesillas (1601-1615) tuvo el acceso necesario para poder representar aquella época de una manera fehaciente. Garcilaso, más bien, tenía que apoyarse en su propia memoria de aquellos tiempos o en la vox populi.

7 Parece que ninguno fue embarcado (Nowack y Julien 1993).

8 López Martínez 1967.

9 Garcilaso 1960: 168. Tampoco se explica que no se mencione a Titu Cusi. Juan Arias Maldonado debió haber estado bien informado de las negociaciones de don Titu Cusi cuando llegó a Espańa, por lo que sorprende que no haya hablado sobre el tema con Garcilaso.

${ }^{10}$ Ocampo (1906) y Alcaya (1906) también cometen muchos errores cuando escriben de la época pretoledana. 
Si leemos a Garcilaso con los criterios del historiador, su texto presenta serios defectos. Pero sería error nuestro tacharle de mentiroso sin pensar en las posibles fuentes de lo que cuenta. Hay otras formas de representación que están obrando en el fondo de lo que Garcilaso narra sobre la época toledana. Por ejemplo, no era necesario terminar la historia de la actuación del virrey Toledo en los Andes con su muerte en España. Garcilaso lo incluye «porque no vaya sola y desacompañada la muerte del Inca don Felipe Tupac Amaro»; por eso, «será razón [que] demos cuenta brevemente de la que tuvo el visorrey don Francisco de Toledo». ${ }^{11}$ A continuación, narra el fin trágico que tuvo el virrey luego de su retorno a España. Su muerte se equipara a la muerte del Inca. El mismo contraste nos hace entender la muerte de Topa Amaru como una muerte ejemplar. Garcilaso elije ejemplos de la buena y la mala muerte para cerrar su obra maestra. Y, de hecho, él no es el único autor andino que representa la muerte de Toledo de esta manera; luego de examinar el texto de Garcilaso a la luz de los documentos, volveremos a este tema.

\section{LA BUENA Y LA MALA MUERTE}

A principios del siglo XVII, cuando Garcilaso escribió los Comentarios reales, ya estaba bien desarrollada la literatura de ars moriendi. Su importancia aumentó durante el curso del siglo XVI, lo que reflejaba la preocupación creciente sobre el pasaje de la vida a la muerte. Ningún cristiano podía prever las circunstancias de su partida y «las agonías de la muerte» eran momentos críticos para la salvación. Lo deseable era prepararse bien: se debía, primero, encargar el alma y los bienes mediante un testamento escrito y, luego, recibir los sacramentos y la extremaunción. Era deseable también estar consciente hasta el momento mismo de la muerte, para no dejar el alma expuesta a las maquinaciones de Satanás, que estaba especialmente activo en los últimos momentos de la vida. Lo indeseable era morir de manera repentina, sin prepararse para la salvación. Parte de la conceptualización de la «buena muerte» era hacerlo en la cama, con todas las disposiciones y preparativos hechos, 
y rodeado por familiares. En cambio, la muerte súbita en la calle era la imagen típica de la «mala muerte». ${ }^{12}$

Topa Amaru murió en el cadalso y, por eso, no parecía ser candidato para una «buena muerte». Justamente por la escenificación pública del acto, el ajusticiamiento se podría poner en práctica como una muerte ejemplar, sobre todo «si el condenado se arrepentía en el último instante y sabía morir digna y cristianamente». Así, "podía constituirse en un eficaz ejemplo demostrativo de que todos, incluso el más miserable, podía realizar la muerte del buen ladrón y salvarse». ${ }^{13}$

El Topa Amaru de Garcilaso era un inocente, no solamente por su forma de comportarse en el momento de la muerte, sino por todo lo que hizo en los días anteriores. Es más, para Garcilaso, el Inca no había cometido ningún delito que justifique su condena: era inocente desde el punto de vista de la ley. Los asaltos y robos de los Incas de Vilcabamba fueron cometidos en época de Manco Inca, su padre. Según Garcilaso, el Inca fue acusado de haber conjurado con sus parientes para levantarse y matar a los españoles, pero esto era imposible, como él bien sabía, "pues su padre no había podido con doscientos mil hombres de guerra sujetar a doscientos españoles que tuvo cercados en aquella misma ciudad [Cuzco], que no era de imaginar que él pretendiese rebelar contra ellos». En vez de resistir a las tropas del virrey que entraron a Vilcabamba para capturarle, «vino con ellos de buena gana», pues esperaba que «le iban a hacer alguna merced como se la hicieron a su hermano don Diego Sairi Tupac». ${ }^{14}$ Pero Garcilaso se equivocaba: los incas ofrecieron resistencia a las tropas que Toledo mandó para capturar al Inca.

El autor pinta a Topa Amaru como un buen cristiano en todo momento, con una conducta ejemplar en los días antes de su muerte, cuando fue sujeto a una catequización intensa:

Demás del buen ánimo con que recibió la muerte aquel pobre príncipe [...] dejó lastimado los religiosos que le ayudaron llevar su tormento [...] y se

\footnotetext{
${ }^{12}$ Martínez Gil 1993: 140-149.

13 Ib.: 155 .

${ }^{14}$ Garcilaso 1960: 169.
} 
consolaron con la magnanimidad que en aquel paso mostró y tuvieron que contar de su paciencia y actos que hacía de buen cristiano, adorando las imágenes de Cristo Nuestro Señor y de la Virgen su madre que los sacerdotes le llevaban delante. ${ }^{15}$

Topa Amaru dijo, luego de ser sentenciado, que recibiría la muerte "contento y consolado». ${ }^{16} \mathrm{La}$ tranquilidad fue característica de su comportamiento hasta el momento mismo de su ejecución. Ese día, Topa Amaru fue llevado por las calles en una mula hasta la plaza, donde se había erigido un tablado. Le esperaban 300.000 personas. A su llegada, una banda de mujeres soltó un gran alarido que expresaba el deseo de ser muertas para acompańarle. El ruido de los gritos y el vocerío era tal que los sacerdotes que acompañaron al Inca incluso le pidieron «que mandase callar a los indios». Garcilaso describe lo que pasó:

El Inca alzó el brazo derecho con la mano abierta y la puso en derecho del oído y de allí la bajó poco a poco hasta ponerla sobre el muslo derecho. Con lo cual sintiendo los indios que les mandaba callar, cesaron de su grita y vocería y quedaron con tanto silencio que parecía no haber ánima nacida en toda aquella ciudad. ${ }^{17}$

Los españoles y el virrey, que estaba mirando oculto desde de una ventana, quedaron asombrados por la obediencia mostrada por la multitud como respuesta a ese gesto. Cuando le cortaron la cabeza, «recibió aquella pena y tormento con la grandeza que los Incas y todos los indios nobles suelen recibir cualquiera inhumanidad y crueldad que les hagan». ${ }^{18}$ Aún sin esta temprana referencia al famoso estoicismo del indio, la muerte del Inca — tal como fue representada por Garcilaso- cumple con las pautas propias para ser considerada como un ejemplo de la buena muerte.

Por el contrario, Toledo sufrió una mala muerte. Garcilaso no revela al principio de los cinco capítulos que dedica a su gobierno que el virrey fuera a terminar mal, pues señala que fue elegido "por su mucha

\footnotetext{
${ }^{15}$ Ib.: 171 .

16 Ib.: 169 .

${ }^{17}$ Ib.: 171 .

${ }^{18} \mathrm{Ib}$.
} 
virtud y cristiandad» y nota que «recibía el Santísimo Sacramento cada ocho días». ${ }^{19}$ El virrey queda relegado en la narración cuando Garcilaso presenta el mal tratamiento recibido por los incas y mestizos del Cuzco luego de ser capturado Topa Amaru. Toledo solamente viene a ser protagonista en el quinto y último capítulo, cuando regresa a España en vísperas de su muerte. Garcilaso afirma que murió trágicamente, no tanto por razón de su poca piedad como en el caso de Topa Amaro, sino por sus pecados de avaricia y orgullo:

Cumplido el término de su visorreinado, que fue muy largo, que según dicen pasó de los dieciseis años, se vino a España con mucha prosperidad y riqueza, que fue pública voz y fama que trajo más de quinientos mil pesos en oro y plata. Con esta riqueza y la buena fama de ella, entró en la corte, donde pensó ser uno de los grandes ministros de España por los muchos servicios que imaginaba haber hecho a la majestad católica en haber extirpado y apagado la real sucesión de los Incas reyes del Perú. ${ }^{20}$

Toledo gobernó al Perú algo más de doce años y no trajo semejante cantidad de dinero a Espańa, pero lo más interesante para nosotros es su recepción por el rey: «La católica majestad [...] recibió el virrey no con el aplauso que él esperaba, sino muy en contra. Y en breves palabras le dijo que se fuese a su casa, que Su Magestad no le había enviado al Perú para que matase reyes, sino que sirviese a reyes». ${ }^{21}$ Este es el famoso refrán que tan fácilmente se ha mantenido en la memoria. Según Garcilaso, Toledo cayó en dos «desfavores»: el uno, por haber sentenciado a Tupa Amaru a la muerte; y el otro, por haber excedido en sus cobranzas a la Hacienda Real. Citando como fuente «los émulos que avisaron al consejo real», Garcilaso escribe lo siguiente:

Sus criados y ministros [de Toledo] habían cobrado su salario pesos por ducados, que como eran cu[ar]enta mil ducados tomaban cada año cuarenta mil pesos y que por el largo tiempo que el visorrey había asistido en el

\footnotetext{
${ }^{19}$ Ib.: 164 .

${ }^{20}$ Ib.: 172 .

${ }^{21} \mathrm{Ib}$.
} 
gobierno de aquel imperio pasaban de ciento y veinte mil ducados los que se habían hecho de daño y agravio a la hacienda real. ${ }^{22}$

La cuantía de cuarenta mil ducados es relevante, y volveré a mencionarlos más adelante, pero quiero seguir aquí con lo que escribió Garcilaso. Dice que se hizo el embargo de «todo el oro y plata» que llevó consigo el virrey, luego del cual «Don Francisco de Toledo, viendo el segundo disfavor que igualaba con el primero, cayó en tanta tristeza y melancolía que murió en pocos días». ${ }^{23}$

Garcilaso no precisa las circunstancias de la muerte del virrey, pero deja entendido que la melancolía y la tristeza ocasionadas por el rechazo de su soberano fueron los motivos más importantes. Como el propósito de un caballero como Toledo en todo momento de su vida era servir a su rey, lo peor que le podría haber pasado era morir en desgracia. Aun cuando Guamán Poma presenta la imagen de Toledo cayéndose muerto en una silla, Garcilaso la describe como una tragedia.

\section{EL RETORNO DEL VIRREY}

Es verdad que Toledo murió pocos días después de volver a su tierra, tal como lo cuenta Garcilaso, pero en circunstancias diferentes. La documentación que se conserva acerca de lo que pasó después de la llegada de Toledo a España nos proporciona una imagen distinta de las cosas. $\mathrm{Al}$ mismo tiempo, nos sirve para rectificar por completo lo que cuenta Garcilaso. Abordaremos brevemente los puntos relevantes.

Garcilaso cuenta que Felipe II reprendió a Toledo cuando le fue a besar la mano en la corte y que pronunció su famoso refrán en aquella ocasión. Este rechazo puso tan triste a Toledo que murió pocos días después. Pero es poco probable que el rey haya reprendido al virrey de esta manera, si es que Toledo logró verse con el rey. Toledo estaba gravemente enfermo cuando llegó a España. Tal estado se remonta a 1574, cuando participó en la guerra contra los indios chiriguanos en el oriente del actual territorio

${ }^{22} \mathrm{Ib}$.

${ }^{23} \mathrm{Ib}$. 
boliviano. Nunca recuperó su salud y pidió licencia para dejar su cargo y volver a España numerosas veces en los siguientes años. El rey la aceptó finalmente en 1580 y nombró a Martín Enríquez como su sucesor. Llegado Enríquez al puerto de Paita, Toledo se embarcó para España y arribó a Sevilla el 15 de septiembre de 1581. En aquel momento, Felipe II estaba en Lisboa, asegurando la corona de Portugal para Espańa. Entonces Toledo pasó directamente allí para besarle la mano. Toledo escribió en una carta del 28 de enero de 1582, dirigida a Mateo Vázquez, secretario de Felipe II, que no había podido «besar las manos de su majestad con la verdad que Dios sabe que deseaba, y a echarme a mí y a mis méritos y trabaxos a sus pies» porque su salud se lo impedía. Pidió irse a su casa porque la humedad de Lisboa, «que es contraria a mi disposición de que yo tengo esperiencia», le hacía mal, tal como le habían aconsejado los médicos del rey. ${ }^{24}$ Es posible que Toledo lograra verse brevemente con Felipe II porque el capitán Francisco de Barrasa, mayordomo de Toledo y su acompañante en el viaje de retorno, escribió que este llegó a su tierra "tan viejo y enfermo como vuestra magestad le vio». ${ }^{25}$ Toledo murió en Escalona, en el condado de Oropesa, el 21 de abril de 1582. ${ }^{26}$ Aun cuando tuviera un encuentro con el rey, es dudoso que hubiera podido hacer la deseada relación de sus servicios e igualmente dudoso que Felipe II le reprendiera como escribió Garcilaso. ${ }^{27}$

${ }^{24}$ Levillier 1935-1942, I: 197-198. Toledo parece desalentado en la carta. No era la última carta del virrey, como Levillier pensaba (1956: 16). Hubo otra, con fecha del 8 de febrero de 1582, también dirigida a Vázquez (Fernández Navarrete, Salvá y Sáinz de Baranda 1842-1895, XCIV: 545-547). Parece que no había salido aún de Lisboa. La segunda carta revela que Toledo ya sabía del problema sobre su cobro de una ayuda de costa en Lima (que menciono más abajo). También se percata de que Vázquez estaba alineado con el Consejo de Indias en su contra. No hay evidencia de que se había visto con el rey.

${ }^{25}$ Levillier 1921-1926, VII: 469; y 1956: 16.

${ }^{26}$ Julien 1999.

${ }^{27}$ Ernst Shäfer (1931) y Roberto Levillier (1956) escribieron cada uno ensayos sobre las relaciones entre Toledo y las Audiencias de Lima y Charcas, por un lado, y entre Toledo y Felipe II, por otro. Sacan conclusiones opuestas: Shäfer se enfoca en el apoyo que Felipe II le prestaba a Toledo y en el poder que tenía el virrey para gobernar, en contra de lo que hubiera querido el Consejo; Levillier, en cambio, argumenta que Toledo 
El rechazo puede tomar distintas formas e, incluso si Felipe II no hizo tal cosa en vida, podríamos interpretar lo que pasó luego de su muerte como un tipo de rechazo. Es verdad, como dice Garcilaso, que Toledo esperaba recibir una merced en gratificación por sus largos años de servicio como virrey del Perú. ${ }^{28}$ Aun antes de dejar el Perú, pidió la encomienda de Andahuaylas en el Cuzco, vacante desde 1570 por la muerte de Diego Maldonado. ${ }^{29}$ También solicitó el cargo de clavero en la Orden de Alcántara, de la cual ya era comendador. Parece que Felipe II le concedió el cargo en su orden —aunque no hubo tiempo para gozarlo—,${ }^{30}$ pero nunca llegó a conferirle ninguna encomienda o renta. Para un caballero que vivía para servir al rey, esta falta de reconocimiento constituía un fuerte rechazo.

Este no es el lugar para tratar en detalle lo que le sucedió a Toledo, pero es importante tener alguna idea acerca de por qué Felipe II no llegó a concederle la merced que deseaba. En suma, lo que imposibilitó la concesión de la merced fueron los juicios que tuvieron lugar en el Consejo de Indias cuando Toledo regresó a España. Primero, el Consejo de Indias descubrió que cuánto había cobrado de sueldo el virrey antes de volver a España. Su sueldo, durante los doce años que ocupó el cargo de virrey, era de 40.000 ducados anuales. Sin embargo, por haber recibido el pago en barras en vez de en reales, libró la cantidad de 41.000 ducados en vísperas

fue abandonado por el rey. Es importante mencionar que Levillier no citó el trabajo de Shäfer ni utilizó la serie de consultas entre el Consejo y el rey que fueron minados por este en su estudio. Ni el uno ni el otro se preocupó de lo que pasó luego de la muerte del virrey. Según Shäfer, «la célebre anécdota de cómo Felipe II le reprendiese por esta muerte a D. Francisco de Toledo cuando, después de vuelto, se presentó al rey, tiene que ser del todo apócrifa, porque un gesto tan teatral es absolutamente extraño al carácter de D. Felipe» (1931: 107, nota 18). Levillier lo tacha de «una fabula garcilasista» (1956: 15). ${ }^{28}$ Un memorial del conde de Oropesa menciona a las mercedes recibidas por otros virreyes y gobernadores del Perú. Según este documento, el virrey Antonio de Mendoza había recibido 20.000 ducados de renta que todavía gozaban sus herederos; el licenciado Lope García de Castro obtuvo una renta de 6000 ducados anuales en la Casa de la Contratación; y los hijos de Martín Enríquez tenían la encomienda de Piedrahita en España, además de una pensión de 4000 ducados en el Perú por dos vidas (Levillier 1921-1926, VII: 477).

${ }^{29}$ Archivo General de Indias, Lima 1, N. 137.

${ }^{30}$ Levillier 1956: 16; y 1921-1926, VII: 469-470. 
de su retorno a España, lo cual hizo con la aprobación de los oficiales reales en Lima. ${ }^{31}$ Garcilaso anotó que Toledo había calculado su sueldo en "pesos por ducados», por lo que había cobrado 120.000 ducados de más. Así, aunque el cronista parece tener alguna memoria del asunto, está errado tanto en las cantidades como en la naturaleza del problema.

Garcilaso no tiene presente el otro pleito que tuvo origen cuando Toledo regresó a la Península. El Consejo de Indias descubrió que había cobrado una ayuda de costa de 10.000 ducados por cada año de los cinco en que estuvo ocupado en la visita general, es decir 50.000 ducados en total. En una carta de 1572, Felipe II había autorizado el pago de los salarios para la visita «de condenaciones de culpados [...] y que los indios ayudasen con comidas y lo que faltase se supliese del crecimiento de tributos». La Audiencia de Lima aprobó una ayuda de costa de 10.000 ducados cada año, pero Toledo quería que le pagasen otro sueldo, como se hacía con los oidores que salían a visitar. Antes de volver a España, el 21 de abril de 1581, el virrey, con los autos y pareceres de los oficiales, mandó librar un pago de 50.000 ducados del receptor general de la visita, quien tenía a cargo una cuenta donde ingresaba el dinero de la tasa que se separaba para pagar «justicias». El Consejo de Indias le había advertido que ellos decidirían lo que era justo. Por eso, al descubrir que Toledo había ordenado el pago, el fiscal lo enjuició por los 50.000 ducados y los intereses respectivos.

Los testamentarios del virrey, representados por su sobrino, el conde de Oropesa, elaboraron su propia relación de demandas, incluyendo el sueldo correspondiente al tiempo de su viaje de regreso, un ídolo y unos lienzos llevados por el juez que embargó los bienes del virrey, y los gastos del virrey relacionados con la visita, calculados en 69.000 ducados. En el curso del proceso, murieron dos de los jueces y hubo un intento de llegar a un concierto entre las partes que fracasó; pero la causa no se terminó

${ }^{31}$ Para un mejor resumen de los cálculos que se hizo para llegar a los 41.000 ducados y cómo fueron recibidos en Sevilla, véase Levillier 1921-1926, VII: 502-504. Si dividimos los 41.000 ducados por los doce años en que el virrey recibió un sueldo en el Perú, sacamos una cifra de 3416 ducados por año, que sería el promedio de las fluctuaciones entre la moneda en barras y la moneda en pesos ensayados. 
hasta 1598, cuando fue sentenciada definitivamente. Los testamentarios recibieron cinco meses de sueldo y no se reconoció el pago de los intereses de los 50.000 pesos. Como los pleitos concluyeron en agosto de 1598, en vísperas de la muerte de Felipe II, el 13 de septiembre del mismo año, ${ }^{32}$ no hubo tiempo para que el rey concediera la merced al antiguo virrey. Parece que se concluyó el asunto con el deceso del monarca. A fin de cuentas, lo que venció a Toledo fue la muerte.

Todo lo anterior se podría pintar como una tragedia, pero aún cuando el caso de la mala muerte pintado por Garcilaso no deja de tener un aire de veracidad, algo falta. Garcilaso mencionó otro «desfavor» en que recayó el virrey cuando llegó a España: el rechazo del rey por haber ajusticiado a Topa Amaru. Aunque la documentación que tenemos se relaciona exclusivamente con los pleitos, hay algunas referencias escasas a la actuación de Toledo al hacer la guerra contra los incas de Vilcabamba y al ajusticiamiento del Inca. Aparecen en los memoriales presentados por sus testamentarios y siempre se presentan en el contexto de una lista de los servicios que hizo su pariente en el Perú que merecían gratificar. ${ }^{33}$ No veían la actuación de su pariente respecto a los incas de Vilcabamba como un lastre, por lo que podemos inferir que las autoridades españolas ante las cuales presentaron sus memoriales vieron la actuación de Toledo con los mismos ojos.

\section{LA MUERTE DEL INCA EN LA MEMORIA ANDINA}

Garcilaso estaba y vivía en España cuando Toledo llegó y durante todo el tiempo que duraron los pleitos. Bien podríamos pensar que lo que

\footnotetext{
${ }^{32}$ Se conservan tres sentencias. Primero, en sentencia definitiva se les concedió a los testamentarios los cinco meses de sueldo que el virrey no había cobrado. El 10 de agosto de 1598, este asunto fue visto en grado de revista con fallo a favor de la sentencia definitiva, con notificación del fiscal del 7 de septiembre del mismo ańo. Finalmente, el 11 de agosto de 1598, los testamentarios fueron absueltos de pagar los intereses de los 50.000 ducados y se puso perpetuo silencio sobre el asunto. Fue decidido el 11 de agosto de 1598, con notificación del fiscal del 7 de septiembre de 1598 (Levillier 1921-1926, VII: 524-529).

${ }^{33}$ Levillier 1921-1926, VII: 493-494 y 501. La única excepción parece ser una referencia a «la justicia que hizo de los ingas» en una consulta del Consejo de Indias (Shäfer 1931: 105), pero es probable que se refiera al juicio que sostuvo contra los incas del Cuzco.
} 
escribió reflejaba algo de lo que pasó allí o, por lo menos, lo que se contaba en la calle acerca del virrey. Pero otra posibilidad se sugiere. Existe otro autor que representa la muerte del virrey como contrapunto a la muerte del Inca y de una manera que nos hace recordar a Garcilaso: Felipe Guaman Poma de Ayala. La semejanza entre estos dos autores adquiere importancia porque no hay motivos para pensar que un autor había conocido lo que escribió el otro; no podría ser un caso de préstamo textual sino de una transmisión oral.

Como Garcilaso, Guaman Poma sitúa la muerte de Topa Amaru en primer plano cuando escribe sobre la época toledana, aunque da cierta importancia también a la visita general y la reforma llevada a cabo por el virrey, lo que está ausente por completo en los capítulos de Garcilaso. Ambos autores se refieren a Topa Amaru en términos que destacan su estatus real: mientras que Garcilaso le llama «el príncipe», Guaman Poma usa el título "ynfante». A este último no le interesa el tema de los mestizos, pero sí menciona el juicio contra los incas del Cuzco que ocurrió al mismo tiempo que la campaña en Vilcabamba ${ }^{34}$ y se refiere a Carlos Inca y Alonso Tito Atauchi por sus nombres.

Ciertos temas relacionados con Topa Amaru son de interés especial para ambos autores, sobre todo su captura y los eventos relacionados con su muerte. Ni Guaman Poma ni Garcilaso se interesan en la campaña de Vilcabamba, que es quizás la mayor diferencia entre sus relaciones y lo que otros autores que escribieron en los años inmediatos a los eventos. ${ }^{35}$ Con referencia a la captura de Topa Amaru, ambos autores insisten en que el Inca no ofreció resistencia a los españoles. Guaman Poma utiliza la captura de Topa Amaru para subrayar uno de los puntos centrales de su obra: los andinos no habían resistido a los españoles, ni tampoco se habían rebelado como Gonzalo Pizarro y Francisco Hernández Girón. ${ }^{36}$

${ }^{34}$ Guaman Poma 1992, II: 417.

${ }^{35}$ Como, por ejemplo, una relación atribuida a Tristán Sánchez que trata del gobierno del virrey Toledo, que parece ser de 1572 (Pacheco, Cárdenas y Torres de Mendoza 1864-1884, VII: 263-279). La muerte de Topa Amaru ocupa un capítulo (Ib.: 279-282). 36 Guaman Poma 1992: 414. 
Garcilaso también niega que los incas de Vilcabamba hayan combatido a las tropas de Toledo, pero no niega la conquista.

Ambos autores narran algunos detalles relacionados con la llegada de Topa Amaru al Cuzco. Según Guaman Poma, el Inca entró descalzo al Cuzco con una cadena de oro al cuello, llevado por el capitán Martín García de Loyola, mientras que el virrey observó la procesión desde la casa de su posada. Delante de él, otro capitán cargaba un ídolo capturado en Vilcabamba, identificado por el autor como Huanacauri, pero que podemos identificar como Punchao. ${ }^{37}$

Guaman Poma omite referencias a la catequización de Topa Amaru, pero nota que fue bautizado antes de ser degollado. A diferencia de Garcilaso, que pinta la escena con más detalle, a este autor no le interesa tanto el drama que tuvo lugar en el día de la muerte: no menciona el alarido que ocurrió cuando el Inca llegó a la plaza del Cuzco ni cómo el Inca calló el ruido con un señal de la mano - aunque sí describe el llanto general que estalló después de que le fuera cortada la cabeza-. Para el cronista, el tema de más interés fue la falta de jurisdicción que tenía el virrey para juzgar al Inca.

En su narración, el obispo Sebastián de Lartaún pidió por la vida del Inca y, luego, «unas mugeres prencipales del Cuzco». Pero era inútil cualquier suplicación porque Toledo se había enojado cuando fue informado que «abia dicho el Ynga, como muchacho y con rrazón, cuando le enbió a llamar, dixo que no quería yr a un mayordomo de un señor Ynga como él». ${ }^{38}$ Desde el punto de vista de Guaman Poma, Toledo no tenía jurisdicción para convocar al Inca, ni mucho menos para juzgarlo y sentenciarlo a muerte. Por ello, el autor reprende al virrey:

Mira, cristiano, esta soberbia y demás de la ley de pérdida que hizo en servicio de Dios y de su Magestad Francisco de Toledo. ¿Cómo puede sentenciar a muerte al rey ni al príncipe ni al duque ni al conde ni al marqués ni al cauallero un criado suyo, pobre cauallero desto? Se llama alsarse y querer ser más que el rrey. Destos dichos caualleros sólo con su poder tiene de conoser

\footnotetext{
${ }^{37}$ Julien 2002.

${ }^{38}$ Guaman Poma 1992, II: 417.
} 
su causa y sentencia el rrey con su persona propia, ni puede conoser la dicha causa su bizorrey ni su audiencia rreal, cino entregalle a sus manos para que como señor o poderoso le perdone o le sentencie a su bazallo mayor de todo uneuerso mundo. Esto es la ley. ${ }^{39}$

Pero ¡la ley de quiénes? Aunque la divinidad de los reyes europeos complicaba la cuestión de si se podría matar a un rey en aquellos tiempos, no estaba en juego la cuestión de quién podría matarle. No es fácil probar que esta idea tiene orígenes en un algún fuero andino, pero hay algunas evidencias a su favor. ${ }^{40}$ En el caso de Topa Amaru, no hay por qué pensar que los españoles le dotaban el estatus de rey. Estaba vigente una capitulación con Titu Cusi, el hermano mayor de Topa Amaru, que exigía que el Inca aceptase ser vasallo del rey de España. Titu Cusi juró su vasallaje en 1567 y la capitulación estaba aprobada por Felipe II. Podríamos acusar a Toledo de ser duro al imponer la pena capital en este caso, pero no hubo ningún impedimento legal.

En la crónica de Guaman Poma, la muerte del virrey no sigue inmediatamente después de la muerte del Inca, sino luego de unos capítulos sobre una visita en la época de Topa Inca en que participó un pariente del autor. ${ }^{41}$ Cuando es tema, merece una página entera, acompañada por el dibujo del virrey asentado en una silla. Guaman Poma escribe que Toledo regresó a España, pero no recibió licencia para entrar a la cámara del rey para besarle la mano: "con este pesadumbre se fue a su casa y no comió y se asentó en una cilla. Asentado, se murió untestates

${ }^{39}$ Ib.: 419.

${ }^{40}$ Tres autores andinos proporcionan evidencias sobre la importancia de establecer equivalencias entre autoridades. Uno es Juan de Santa Cruz Pachacuti, que reproduce una canción, cantada por el seńor de Hatunqolla durante el matrimonio de Viracocha Inca, el octavo Inca de la geneaología oficial, en la que compara su estatus con el estatus de Viracocha (Santa Cruz Pachacuti 1993: 217). Otro es Titu Cusi, quien observa que el corregidor del Cuzco, el doctor Gregorio Cuenca, no ocupa el mismo plano que él, pues él se compara con el propio rey de España (Julien 2006: 83). La prueba de que esta preocupación es andina y no espańola viene de Guaman Poma, expuesta más abajo, que riñe amargamente sobre el hecho de que un criado del rey haya tenido la soberbia de matar al Inca.

${ }^{41}$ Guaman Poma 1992, II: 420-423. 
y despidió desta uida. Y acabó su uida sentiéndose el dolor de no uer la cara de su rey y señor». ${ }^{42}$ Toledo no murió intestado, ${ }^{43}$ pero esta referencia y la manera en que su muerte es representada-sentado en una silla y no en una cama- hace posible identificar este episodio en la crónica de Guaman Poma como un caso de la mala muerte.

Hay otra semejanza. Como Garcilaso, Guaman Poma identifica el pecado responsable del trágico fin del virrey: la soberbia. Esta es referida cuando Guaman Poma menciona la falta de jurisdicción de Toledo para juzgar al Inca. Y vuelve sobre este punto cuando describe su muerte:

De los males que había hecho en este rreyno, ací al Ynga como a los prencipales yndios y a los conquistadores deste rreyno, ues aquí, caualleros, la soberuia que tiene un mandado pobre. Se quiso alsarse como se alsó y mató a un rrey y señor deste rreyno. No pudiendo conoser la causa, cino el mismo rrey y señor a de sentenciar y firmar pa[ra] la sentencia y muerte de otro señor y rrey. Y ací la soberbia mató a don Francisco de Toledo. ${ }^{44}$

Garcilaso también menciona la soberbia del virrey, aunque su lectura de que el virrey tuvo una mala muerte fue porque pecaba sobre todo de avaricia.

Las semejanzas en la manera de estructurar sus narrativas, el uso del contraste entre la buena y la mala muerte, y el fuerte contenido moral parecen ser aspectos de una versión de esta historia que ambos autores usaban como fuente. Esta versión enfatiza el drama de la muerte del Inca que se realizó públicamente en el Cuzco. La escenificación es importante, y podemos verlo también en el encuentro entre Toledo y el rey que relata Garcilaso. Ambos autores tienen sus coincidencias, pero no son versiones independientes la una de la otra. Si acertamos bien en que beben de una fuente común, debemos de preguntar ¿cuál es el origen de esta historia? Guaman Poma estaba en el Perú y Garcilaso en España cuando Toledo ocupaba el cargo de virrey, y ninguno cruzó el mar en

\footnotetext{
42 Ib.: 424 .

43 Para el testamento de Toledo, fechado el 11 de marzo de 1580, véase Levillier 1935 1942, I: 90-181.

44 Guaman Poma 1992, II: 424.
} 
los siguientes años. Es probable que tuviera su origen en los Andes. La muerte del Inca fue un punto traumático en la historia de la conquista para las poblaciones andinas y es lógico que aparezca una manera de representarla que satisficiera al pueblo que sentía fuertemente este evento.

Hay otra confirmación de nuestra propuesta. Esta versión no es la única historia de la muerte del Inca; otra versión de la misma historia trata de la muerte de Atahualpa y no de Topa Amaru. ${ }^{45}$ Esta otra versión tiene una trayectoria muy larga en los Andes y sigue siendo representanda en la sierra andina hasta hoy. ${ }^{46}$ La existencia de más de una versión de la misma historia subraya la importancia del tema en la memoria andina. Garcilaso mantenía contacto con el Perú. Es perfectamente posible que él la haya escuchado de alguna visita que tuvo; no dejó de ser un autor andino por el simple hecho de establecerse en España.

\section{LA HISTORIA VS. LA MEMORIA}

Queda por definir un término para referirse a la memoria colectiva que se transmite de boca en boca. La mejor palabra en este caso sería memoria, aun cuando tiene otros sentidos, pues es importante dibujar una diferencia entre historia y memoria. En los siglos XVI y XVII, existía un género fácilmente reconocible como historia, con sus propias normas y pautas, aunque estas eran diferentes de aquellas que rigen a la historia moderna. La historia siempre trata de ser fehaciente a lo que pasó. Se fundamenta en evidencias. La existencia de estas y el acceso del historiador a las mismas son factores que convalidan lo que se escribe. $\mathrm{Al}$ mismo tiempo, hay otras versiones de la historia que circulan de boca a boca. Aparecen cuando un tema tiene un interés especial para una colectividad. No tienen autoría fija. Reflejan algo fehaciente, pero no buscan la verdad en la precisión sino en la resonancia de lo que se cuente

45 Se nota un interés creciente, a partir del siglo XVII, en la captura de Atahuallpa en Cajamarca y su ajusticiamiento por Pizarro. Por ejemplo, Giovanni Anello Oliva dedica mucho espacio al tema, en comparación con la poca mención que hace de los Incas de Vilcabamba (1998: 93, 125-139). La muerte de Atahuallpa también vino a ser tema en el arte visual (Gisbert 1980: 199-204).

46 Burga Díaz 1988. 
con los valores de las personas que lo repiten. Satisfacen una necesidad común de decir una verdad importante. El tema de la muerte del Inca cumple admirablemente con este propósito.

La separación de géneros no es siempre fácil y, como hemos visto, en el caso de los Comentarios reales, un autor puede beber de diversas fuentes. Cuando preguntamos si vale la pena hacer la separación, pienso que sí. Si no la hacemos, no podemos rescatar el género de la memoria que acabo de definir, pues se conserva en textos escritos. Aun cuando nuestra meta se limita a entender algo acerca de nuestro autor Garcilaso, nos importa. Cuando Garcilaso concluye su obra maestra con el tema de la muerte del Inca, nos muestra que, a pesar de los largos años que ha pasado en España, todavía comparte los valores de su pueblo de origen. La otra razón para separar la memoria de lo que podemos definir como historia sería para cumplir con nuestra función como historiador. Solamente así podríamos decir que Toledo sufrió una mala muerte, no aquella que nos cuentan Garcilaso y Guaman Poma, sino la propia suya.

\section{BIBLIOGRAFÍA}

Alcaya, Diego Felipe de. 1906. «Relación del padre Diego Felipe de Alcaya, cura de Mataca». En Maurtua, Víctor M. (ed.). Juicio de Limites entre el Perú y Bolivia. Prueba peruana presentada al gobierno de la república Argentina. Barcelona: Imprenta de Henrich y Comp., t. IX, 124-144.

Burga Díaz, Manuel. 1988. Nacimiento de una utopia: muerte y resurrección de los Incas. Lima: Instituto de Apoyo Agrario.

Fernández Navarrete, Miguel; Salvá, Miguel y Pedro Sáinz de Baranda (eds.). 1842-1895. Colección de documentos inéditos para la historia de España. Madrid: Ginesta Hermanos, Impresores de la real casa, 113 vols.

Garcilaso Inca de la Vega. Historia general del Perú. 1617. Córdoba: Viuda de Andrés Barrera.

. 1960. «Historia general del Perú. Segunda parte de los Comentarios reales». En Obras completas del Inca Garcilaso de la Vega. Edición de Carmelo Sáenz de Santa María. Madrid: Ediciones Atlas, t. IV.

Gisbert, Teresa. 1980. Iconografía y mitos indigenas en el arte. La Paz: Gisbert y Cía. Guaman Poma de Ayala, Felipe. 1992. El primer nueva corónica y buen gobierno. Edición de John V. Murra y Rolena Adorno. México, D. F.: Siglo Veintiuno, 3 vols. 
Guillén Guillén, Edmundo. 1977. «Documentos inéditos para la historia de los incas de Vilcabamba: La capitulación del gobierno español con Titu Cusi Yupanqui». Historia y Cultura. Núm. 10: 47-93.

Herrera y Tordesillas, Antionio de. 1601-1615. Historia general de los hechos de los castellanos en las islas i tierra firme del mar oceano. Madrid: Imprenta Real.

Julien, Catherine. 1999. «History and Art in Translation: The Paños and other Objects Collected by Francisco de Toledo». Colonial Latin American Review. Vol. 8, núm. 1: 61-69. . 2002. «Punchao en España». En Flores Espinoza, Javier y Rafael Varón Gabai (eds.). El hombre y los Andes. Homenaje a Franklin Pease G. Y. Lima: Pontificia Universidad Católica del Perú. https://doi.org/10.4000/books.ifea.6710 . 2006. «Titu Cusi Yupanqui amenaza declarar la guerra». En Zevallos-Aguilar, Juan; Takahiro Kato y Luis Millones (eds.). Ensayos de cultura virreinal latinoamericana. Lima: Universidad Nacional Mayor de San Marcos, 79-96. 2007. «Francisco de Toledo and his Campaign Against the Incas». Colonial Latin American Review. Vol. 16, núm. 2: 239-268.

Levillier, Roberto. 1921-1926. Gobernantes del Perú. Cartas y papeles, siglo XVI. Madrid: Imprenta de Juan Pueyo, 14 vols. . 1935-1942. Don Francisco de Toledo. Madrid, 4 vols. . 1956. «Don Felipe II y el virrey Toledo; un duelo de doce años». Revista de la Universidad de Buenos Aires. V época, año 1, núm. 2: 3-17.

López Martínez, Héctor. 1967. "Un motín de mestizos en el Perú, 1567». Revista de Indias. Vol. 24, núms. 97-98: 367-381.

Martínez Gil, Fernando. 1993. Muerte y sociedad en la España de los Austrias. México, D. F.: Siglo Veintiuno Editores.

Nowack, Kerstin. 2006. «Las mercedes que pedía para su salida: the Vilcabamba Inca and the Spanish state, 1539-1572». En Cahill, David y Blanca Tovías (eds.). New world, first nations: native peoples of Mesoamerica and the Andes under colonial rule. Brighton y Portland: Sussex Academic Press, 57-91.

Nowack, Kerstin y Catherine Julien. 1993. «La campaña de Toledo contra los señores naturales andinos: el destierro de los Incas de Vilcabamba y Cuzco». Historia y Cultura. Núm. 23: 15-81.

Ocampo, Baltasar de. 1906. «Descripción de la provincia de Vilcabamba». En Maurtua, Víctor M. (ed.). Juicio de Limites entre el Perú y Bolivia. Prueba peruana presentada al gobierno de la república Argentina. Barcelona: Imprenta de Henrich y Comp., t. VII, 308-344.

Oliva, Giovanni Anello. 1998. Historia del reino y provincias del Perú. Edición de Carlos M. Gálvez Peña. Lima: Pontificia Universidad Católica del Perú.

Pacheco, Joaquín; Cárdenas, Francisco y Luis Torres de Mendoza. 1864-1884. Colección de documentos inéditos relativos al descubrimiento, conquista y organización de las antiguas posesiones españoles de América y Oceania, sacados de los 
archivos del reino, y muy especialmente dél de Indias. Madrid: Imprenta de Frias y Compañía, 42 vols.

Santa Cruz Pachacuti Yamqui Salcamaygua, Juan de. 1993. Relación de antigüedades deste reyno del Pirú. Cuzco: Centro de Estudios Regionales Andinos Bartolomé de Las Casas.

Shäfer, Ernst. 1931. «Felipe II, el Consejo de Indias y el virrey D. Francisco de Toledo». Investigación y Progreso. Año V, núms. 7-8: 103-107.

Titu Cusi Yupanqui, Diego de Castro. 1985. Ynstruçión del ynga Don Diego de Castro Titu Cussi Yupangui para el muy ilustre Señor el licenciado Lope García de Castro, governador que fue destos reynos del Piru. Lima: El Virrey. 